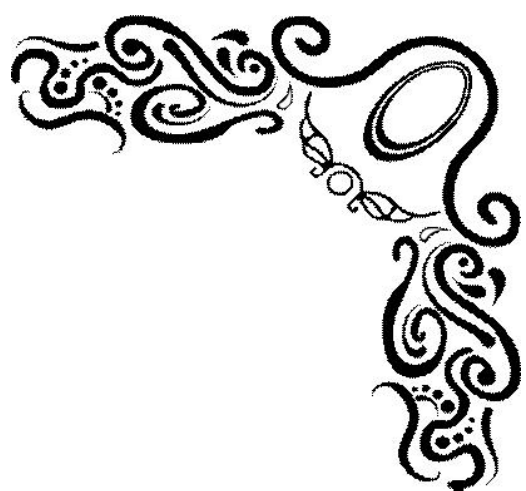

شفاعات النبي صلى اللّه عليه وآله وسلـم في الدنيا

دراســـة تحليليـة

إعـــــاد:

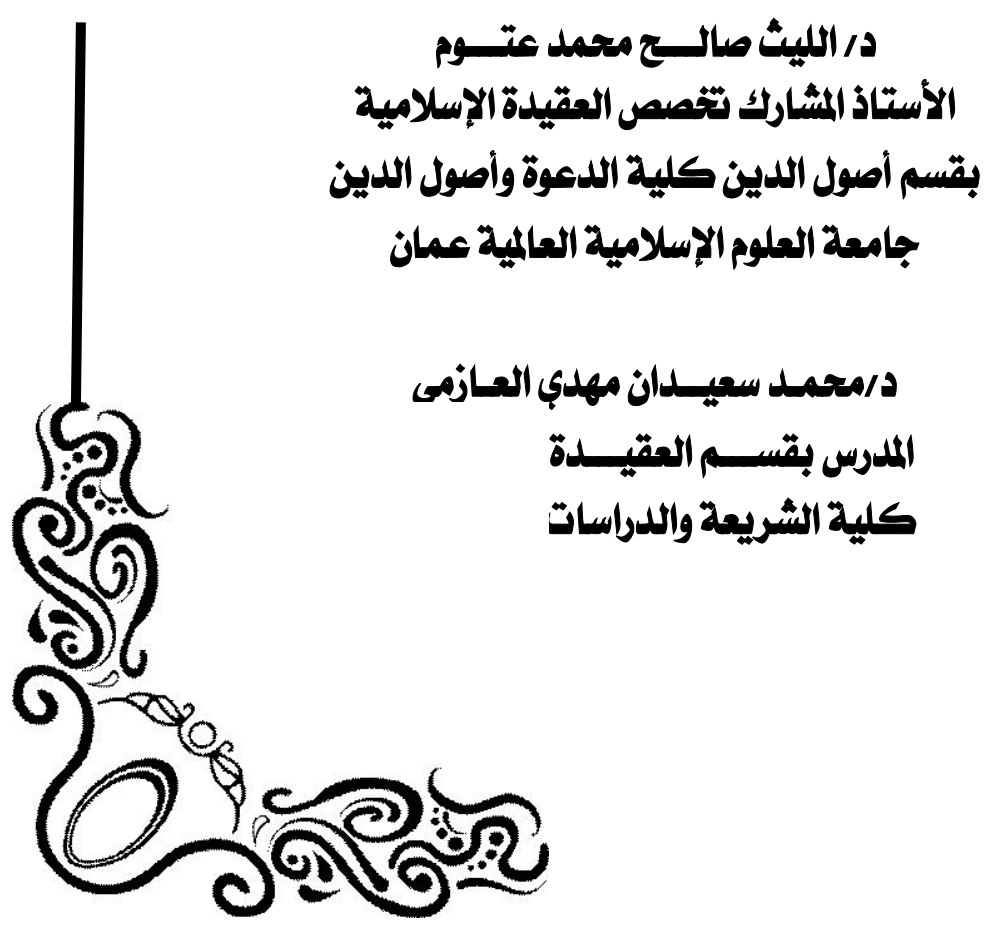


العدد الخامس والثلاثون .
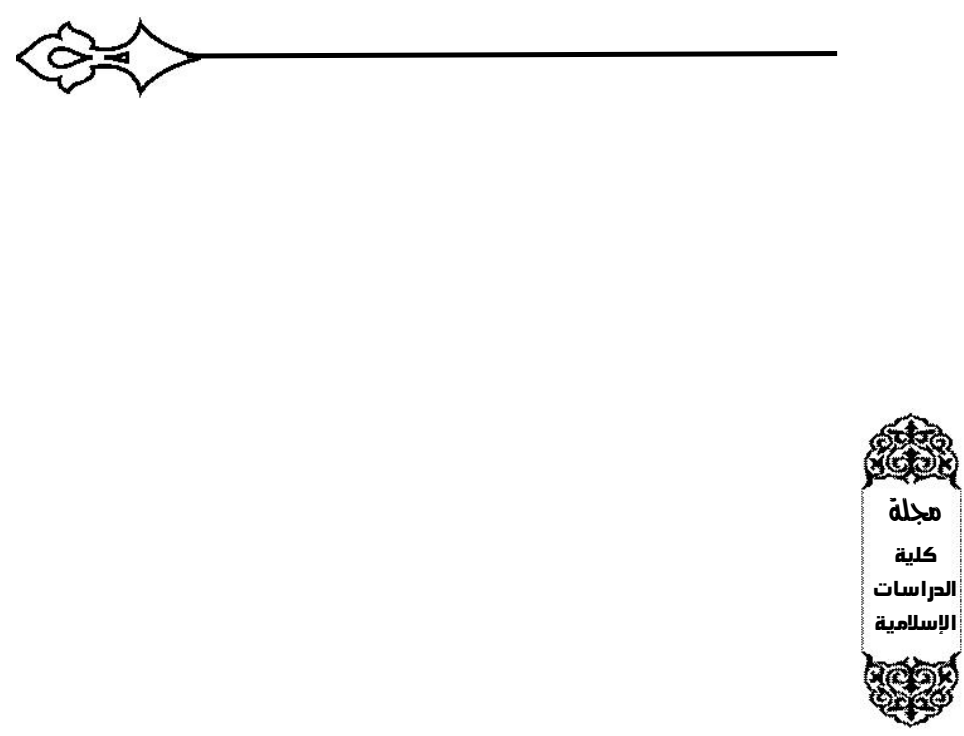

$\Leftrightarrow$ 


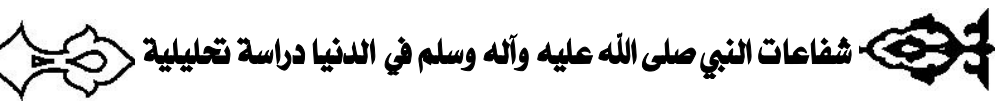
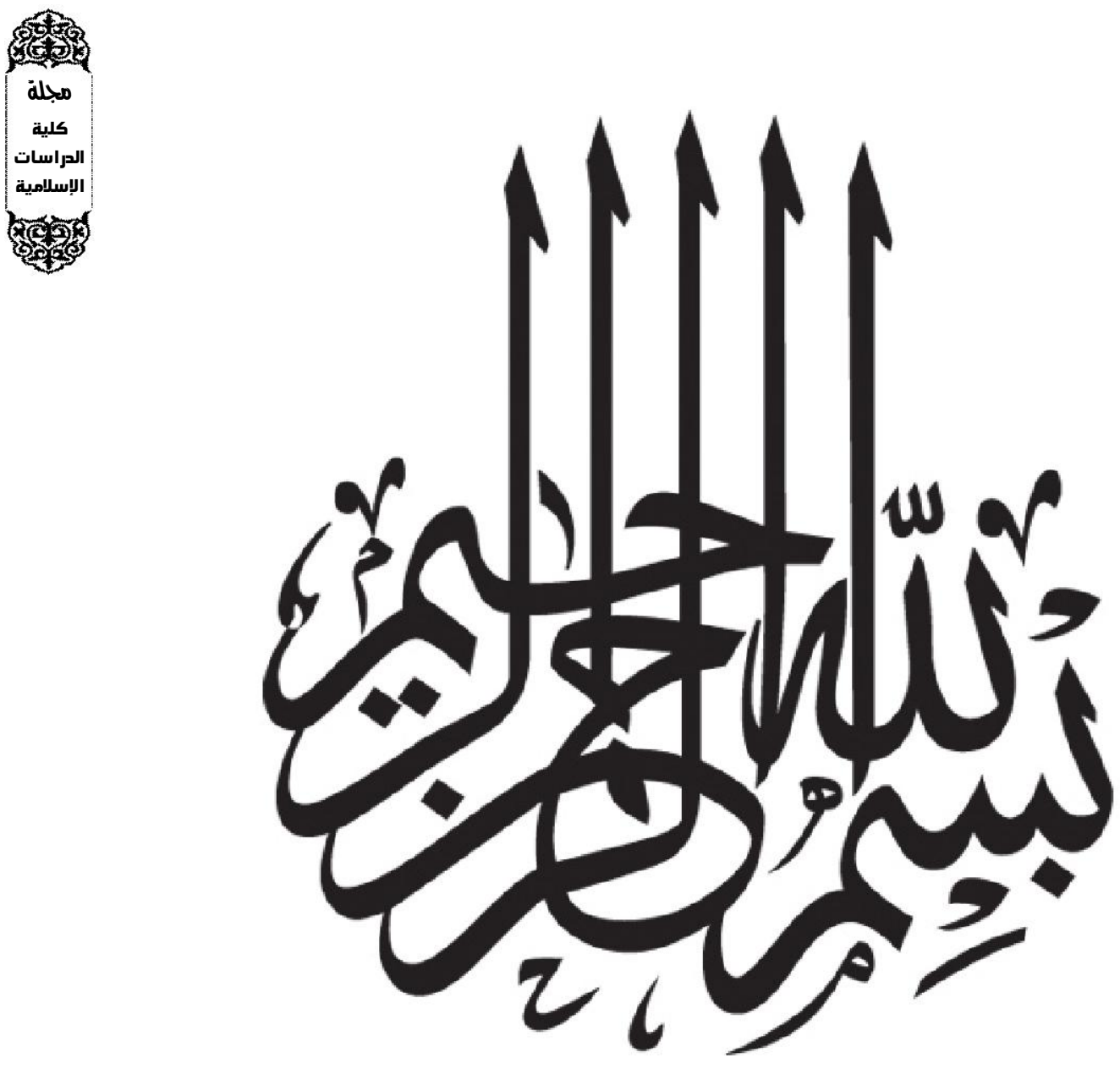
العدد الخامس والثلاثون .
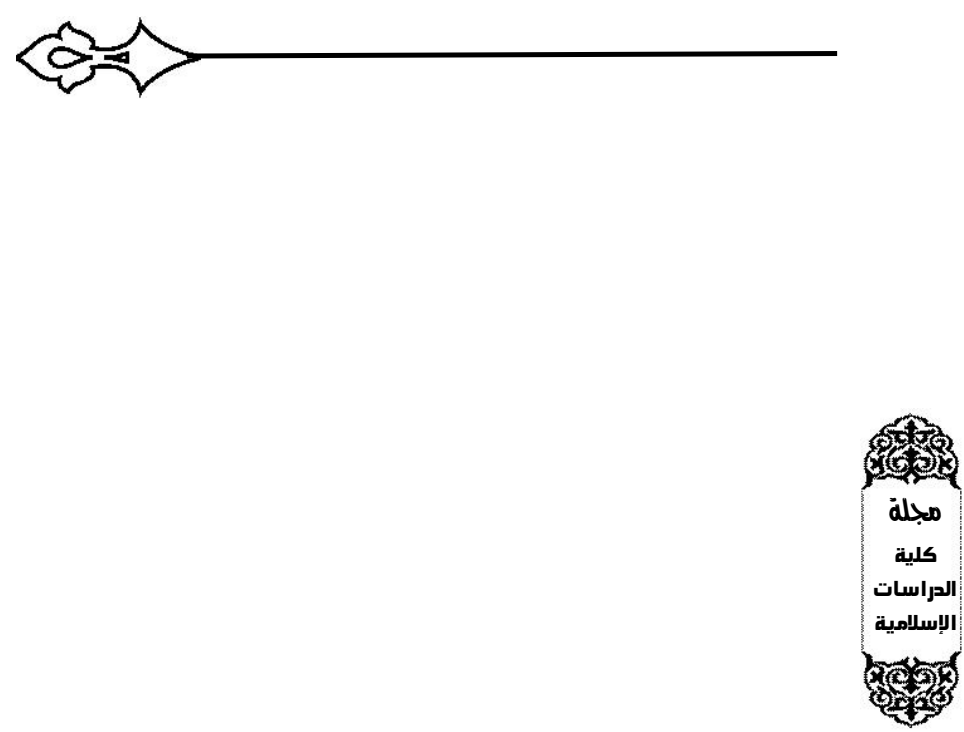

$\Leftrightarrow$ 


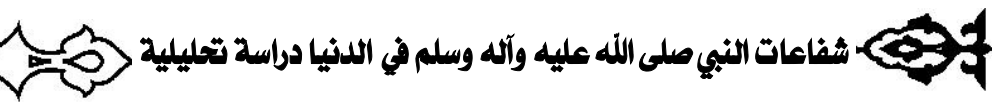

\section{ملغــــ البحــ}

يتكلم البحث عن معنى الشفاعة لغةً واصطلاحَّا، وبيان مفهومها الشرعي وأركانها

وأنواعها وأسبابها وشروطها، وأغلب من تناول موضوع الشفاعة ذكر معنى الشفاعة في

الآخرة، ولذلك في هذا البحث سوف نسلط الضوء على شفاعة النبي - صلى الله عليه وسلم في الدنيا، وبيان الوقائع العملية لشفاعاته- صلى الله عليه وسلم - في الدنيا، وضرب الأمثلة على ذلك سواءً شفاعته للكفار أو شفاعته للحيوانات أو شفاعته للمسلمين، ولذلك تدور مشكلة البحث حول السؤال الرئيس: هل كان للنبي- صلى الله عليه وسلم - شفاعات في الدنيا؟ وهل ثبت عنه تلك الشفاعات؟ وإذا ثبت: فهل كانت شفاعته مقتصرة على المسلمين أم أنها كانت للمسلمين والكافرين أم أنها كانت شاملة لكل المخلوقات. وخلص البحث إلى أن الشفاعة ثابتة له- صلى الله عليه وسلم - في الدنيا كحا هي في الآخرة، وأن شفاعته في الدنيا شاهد ودليل على شفاعته في الآخرة، وأنه- صلى الله عليه وسلم - لم يشفع إلا لمن يستحقها، وأن شفاعته- صلى الله عليه وسلم - كانت للمسلمين والكفار والحيوانات. الكلمات الدالة: الثفاعة- التوسط - العفو - الرحمة. 


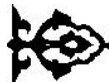

العدد الخامس والثلاثون

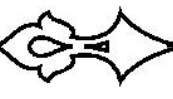

INTERCESSIONS OF THE PROPHET (PBUH) IN THIS

WORLD: AN ANALYTIC STUDY

.DR AL-LAITH SALEH MUHAMMAD ATTOUM, ASSOCIATE PROFESSOR, DEPARTMENT OF FOUNDATIONS OF RELIGION, FACULTY OF DA'WA AND FOUNDATIONS OF RELIGION, THE WORLD ISLAMIC SCIENCES AND EDUCATION UNIVERSITY, AMMAN e.mail: laith.saleh@gmail..com

AND

DR MUHAMMAD SA'IDAN MAHDI AL-'AZMI, ASSISTANT

PROFESSOR, DEPARTMENT OF ISLAMIC CREED AND ISLAMIC CALL, FACULTY OF SHRI ${ }^{\circ}$ AH AND ISLAMIC LAW

Abstract

This research paper deals with the linguistic meaning of intercession as well as its meaning as a term, and explains its concept in Islam. It also clarifies its basic elements, types, causes, and conditions. Most of those who tackled the topic of intercession have tackled the meaning of intercession only in the hereafter. I have shed light on the intercession of the Prophet (pbuh) in this world, and explained the practical events when the Prophet (pbuh) interceded. I have given examples of the Prophet's intercession whether this intercession was for unbelievers, animals, or Muslims. Therefore, the main questions of this paper are as follows: Did the Prophet (pbuh) intercede in this world? Was his intercession confirmed? If yes, was his intercession for Muslims only? Or was it for Muslims and unbelievers as well? Or was it for all creatures? The research has proved that the intercession of the Prophet (pbuh) has existed in this world and it will exist in the hereafter, that his intercession in this world is a proof that he will intercede in the hereafter, that he (pbuh) interceded only for those who deserved his intercession, and that his intercession was for Muslims, unbelievers and animals alike.

Key words: intercession - this world -forgiveness - mercy

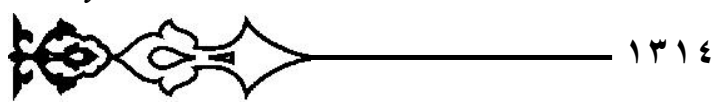




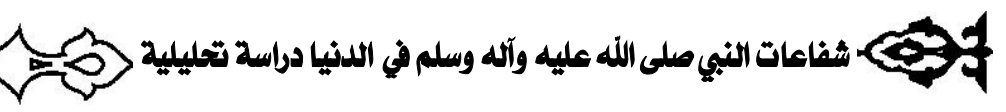

$$
\text { بسم الله الرحن الرحيم }
$$

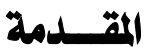

الحمد لله رب العالمين، والصلاة والسلام على سيدنا محمد وعلى آله وصحبه أجمعين، ومن

$$
\text { تبعهم بإحسان إلى يوم الدين، وبعد: }
$$

فإن الله قد أكرم نبيه محمد صلى الله عليه وآله وسلم، وفضله على سائر الأنبياء والمرسلين، وخصه بمزايا وخصائص دون سائر الخلق أجمعين، ومن هذه المزايا شفاعته العظمى في الآخرة لكل الخلق لتعجيل الحساب، وشفاعته لأهل الكبائر من أمته صلى الله عليه وآله

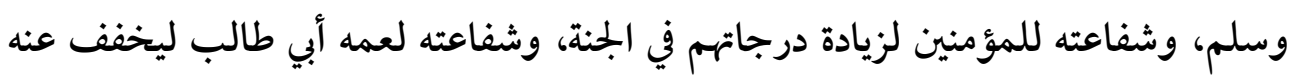

$$
\text { العذاب، وغيرها، وهذه الشفاعات كلها جاءت في الآخرة. }
$$

وقد كتب غير واحد من الباحثين في هذا الموضوع ـ أعني شفاعة النبي صلى الله عليه وآله

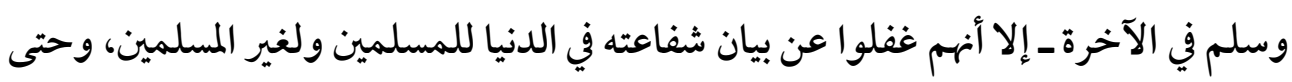
للعجاوات والحيوانات، وللإنس والجن، وحتى للملائكة (1). فجاء هذا البحث ليسلط الضوء على شفاعته صلى الله عليه وآله وسلم في الدنيا لكل

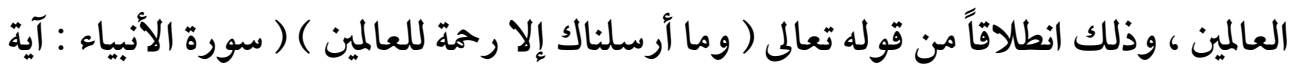

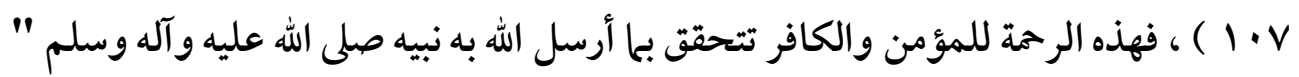

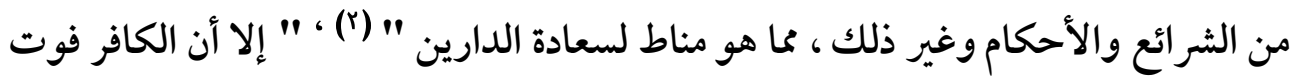

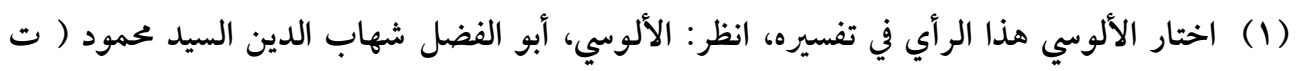
ITV .

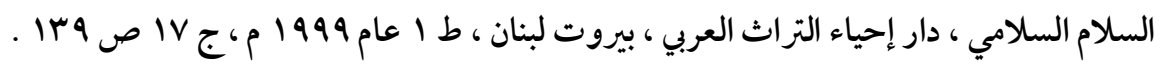

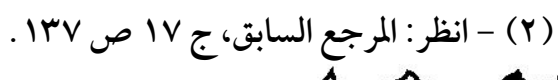




\section{(2)}

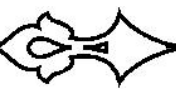

على نفسه الانتفاع بذلك ، وأعرض لفساد استعداده عحا هنالك " (') ، ويحتمل أن تكون

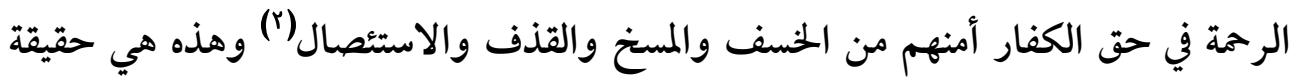

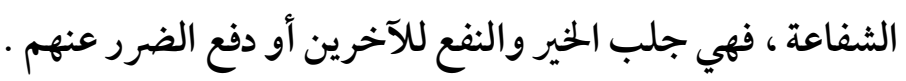
وقد جاء نبينا صلى الله عليه وآله وسلم برسالة الإسلام ـ خاتمة الرسالات ـ للعالمين هدى"

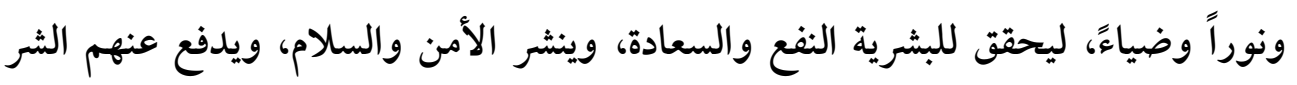
والجهل والغواية، وفي هذه المعاني تتحقق معنى الشفاعة، يقول ابن القيم: " فلولا النبوات لم

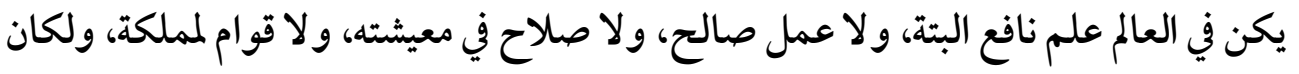
الناس بمنزلة البهائم والسباع العادية، والكلاب الضارية التي يعدو بعضها على بعض ، وكل

دين في العالم فمن آثار النبوة " (") . ومن جانب آخر، فقد كان وجود شخصه الكريم صلى الله عليه وآله وسلم في حد ذاته

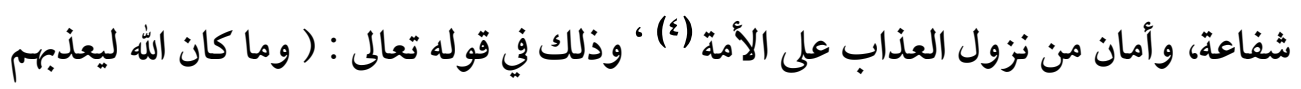

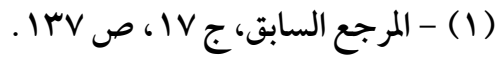

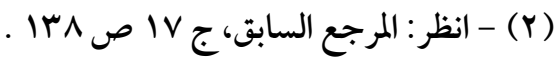

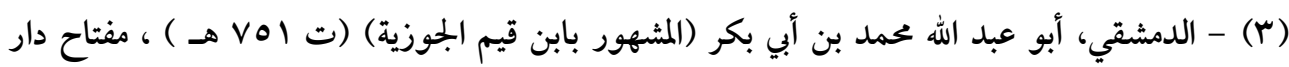

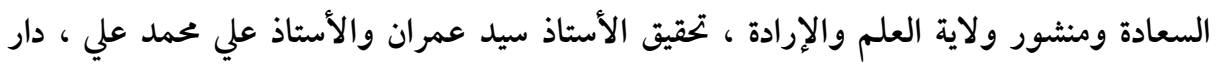

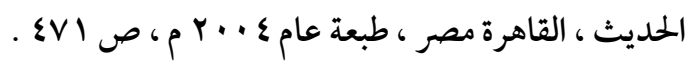

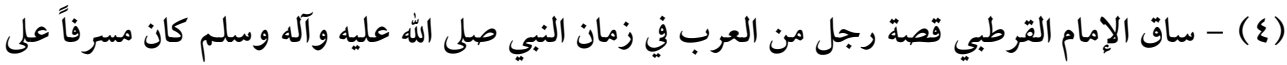

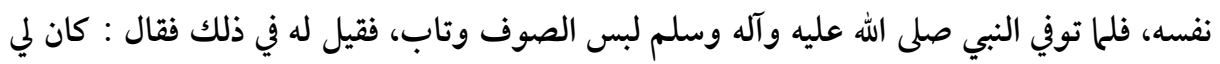

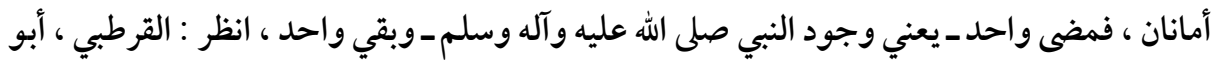

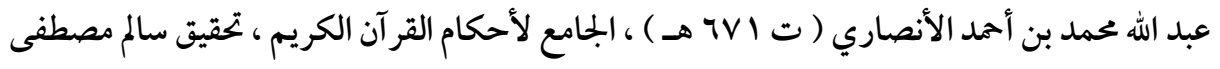

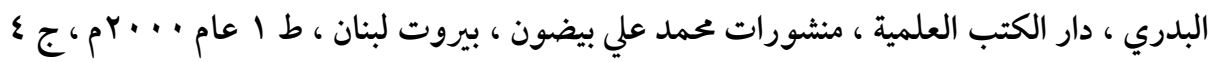

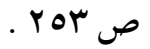




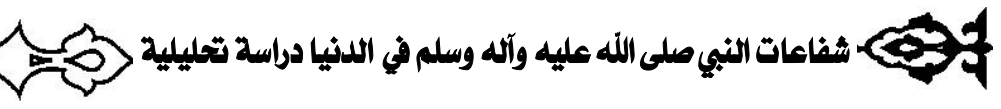

وأنت فيهم وما كان الله معذبهم وهم يستغفرون ) ( سورة الأنفال : آية سب ) ، فإن الله تعالى لم يعذب أهل قرية حتى يخرج النبي منها والمؤمنون ، ويلحقوا بحيث أمروا(1) ، وهذا المعنى دفع الضرر عن الغير - متحقق في الشفاعة . أولأ: أهمية البحث البحث تكمن أهمية البحث في أن موضوع الشفاعة مما اختلفت فيه الفرق الإسلامية كالمعتزلة مع

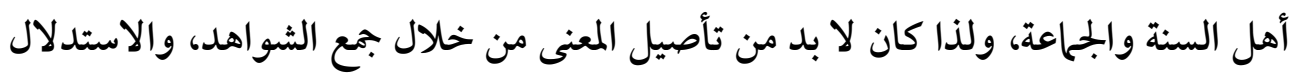

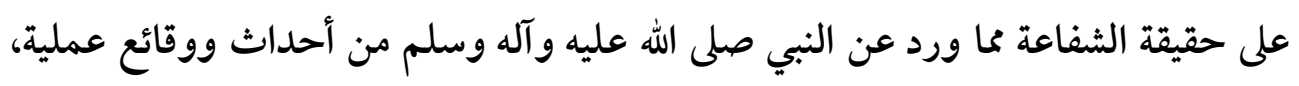
تدلك على أن الشفاعة حق في الآخرة كما هي في الدنيا، ومن ينكر هذا المعنى فإنما ينكر

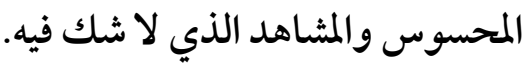
ثانياً: أهداف البحث

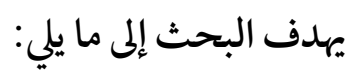

1 - بيان مفهوم الشفاعة والتأصيل الشرعي لها وأركانها وأنو اعها وأسبابها وشروطها. r - بيان الوقائع العملية لشفاعات النبي صلى الله عليه وآله وسلم في الدنيا من شفاعته

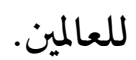

\section{ثالثاً: مشكالة البحث وأسئلته}

تدور مشكلة البحث حول السؤال الرئيس: هل كان للنبي صلى الله عليه وآله وسلم شفاعات في الدنيا؟ وهل ثبتت عنه تلك الشفاعات؟ وإذا ثبتت: فهل كانت شفاعته مقتصرة

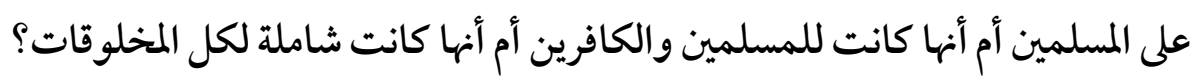

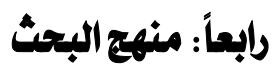
تستخدم الدراسة المنهج التحليلي، الذي يقوم على تحليل المعلومة لاستنباط المعرفة منها ، ثم

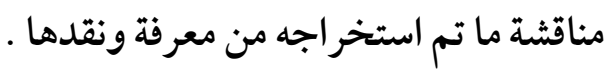

$$
\text { (1) - انظر : المرجع السابق ، ج ع ص ror }
$$



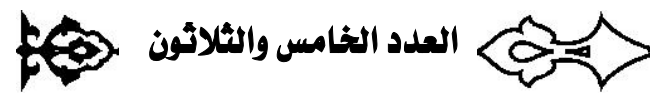

خامساً: الدراسات السابقة لا توجد دراسات سابقة في الموضوع، إلا أن هناك دراسات متعلقة به من جانب آخر، وهو

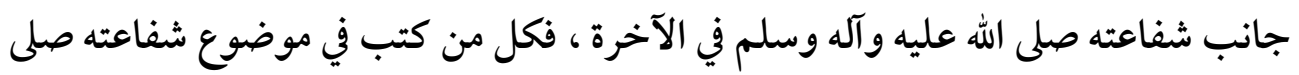
الله عليه وآله وسلم اقتصر على شفاعته في الآخرة ، اذكر منها على سبيل المثال لا الحصر ما ما يلي

1 - كتاب الشفاعة عند أهل السنة والجماعة، للشيخ ناصر الجديع.

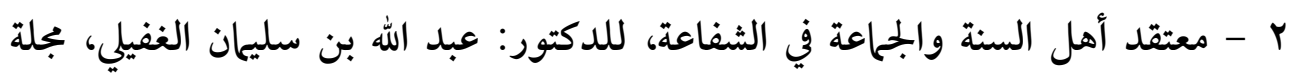

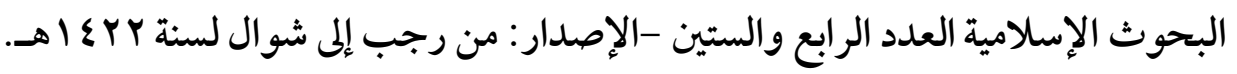

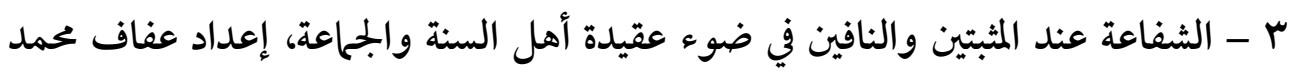
الونيس، رسالة ماجستير، جامعة الملك سعود ، كلية التربية ، قسم الدراسات الإسلامية ،

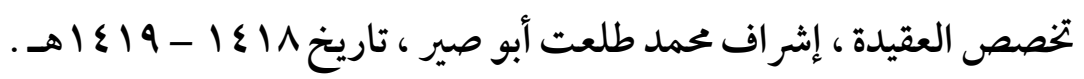

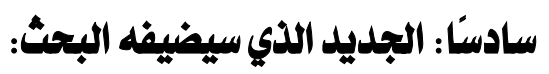

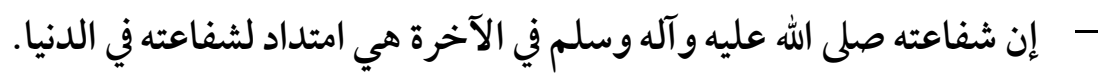
- - - إن الشفاعة في الدنيا إثبات لشفاعته في الآخرة. - - - إن الشفاعة في الدنيا جائزة لفعله صلى الله عليه وآله وسلم. - - - إن الشفاعة في الدنيا تأصيل لمعنى الشفاعة في الآخرة.

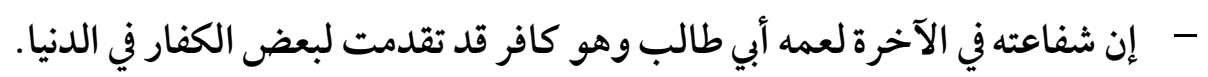
سابغا: خطة البحث وقد اقتضت الدراسة أن تكون على النحو التالي:

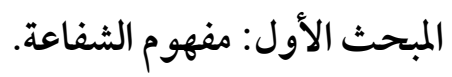
المطلب الأول: الشفاعة لغة واصطلاحاً. المطلب الثاني: التأصيل الشرعي للشفاعة. 


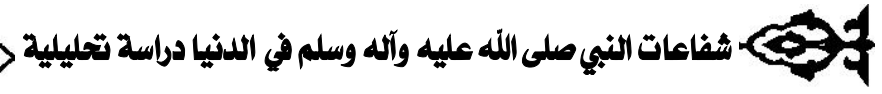

المطلب الثالث: أركانها وأنواعها وأسبابها وشروطها.

المبحث الثاني: شفاعات النبي صلى الله عليه وآله وسلم للعالمين.

المطلب الأول: شفاعته صلى الله عليه وآله وسلم للكفار .

المطلب الثاني: شفاعته صلى الله عليه وآله وسلم للحيوانات .

المطلب الثالث: شفاعته صلى الله عليه و آله وسلم للمسلمين .

الخاتمة. 


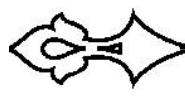

\section{المبحث الأول: مفهوم الشفاعة}

المطلب الأول : الشفاعة لغة واصطلاحماً.

أولأ: لغة: مصدر من الشفع ضد الوتر ، تقول : كان وتراً فشفعته شفعاً ، وشفع الوتر من

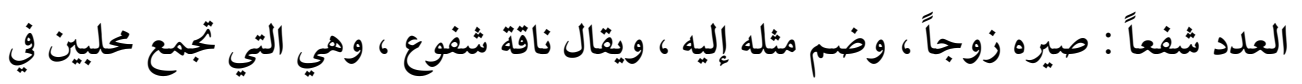
حلبة واحدة ، وشاة شفوع وشافع : شفعها ولدها ، وشفع لي بالعداوة : أعان علي واحداً

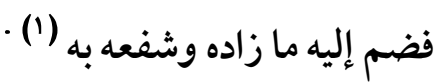

" وشفع إلى فلان: توسل إليه بوسيلة، واستشفع : طلب الناصر " (؟) ·

ثانياً: اصطلاحاً:

إن التعريف الاصطلاحي لم يخرج عن الدلالة اللغوية كثيراً، إذ الشفاعة هي : "السؤال في

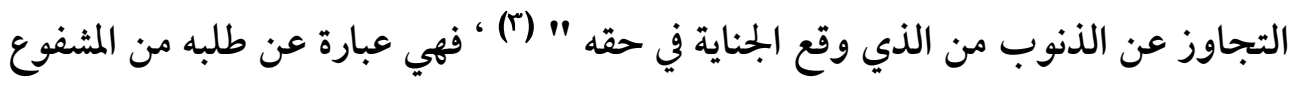

(1) - انظر: ابن منظور، أبو الفضل جمال الدين محمد بن مكرم ( ت ) ، لسان العرب ، طبعة مراجعة

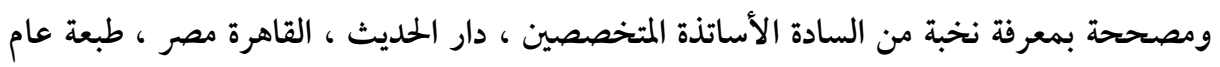

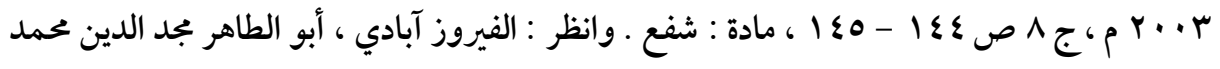

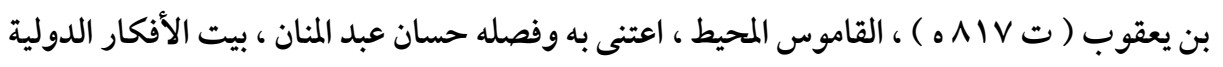

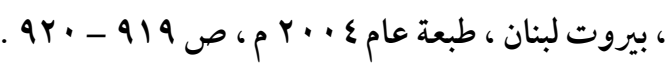

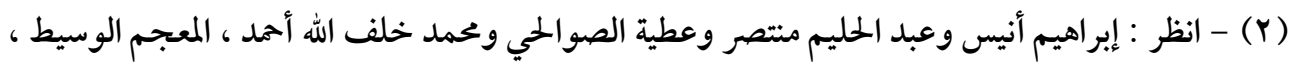

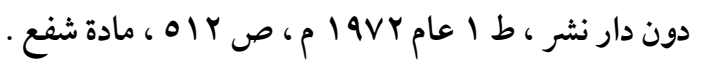

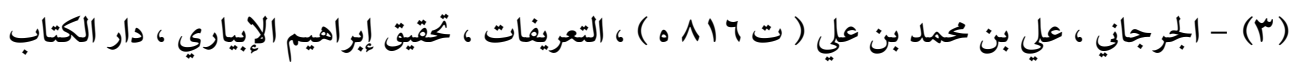

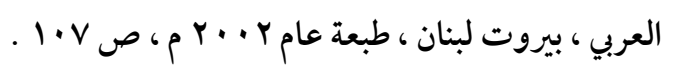

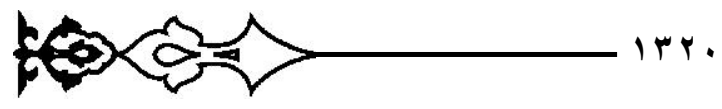




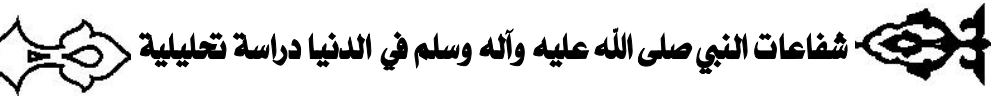

إليه أمراً للمشفوع له ، و التوسط للغير بجلب منفعة أو دفع مضرة (1) .

وذكر التهانوي بأهها : " سؤال فعل الخير ، وترك الضرر عن الغير لأجل الغير ، على سبيل

الترع " (זّ) ، وجاء في قاموس العقيدة بأن الشفاعة : " طلب من الله أن يعفو عمن استحق

عقوبة أو لرفع درجته " (") ، إلا أن هذا التعريف يحصر معنى الشفاعة في الآخرة دون الدنيا ،

ولا يمنع الشرع من الثفاعة في الدنيا .

\section{المطلب الثاني : التأصيل الشرمي}

دلت النصوص الثرعية من القرآن الكريم والسنة النبوية المطهرة على ثبوتها بشروطها ،

وهي في هذا الباب متضافرة متواترة ، من هذه الأدلة :

1 - قوله تعالى : " فما تنفعهم شفاعة الشافعين " ( سورة المدثر : آية رقم ^؟ )

يقول القرطبي : " هذا دليل على صحة الشفاعة للمذنبين " (؛) ، فلو لم تكن هناك شفاعة لغير الكافرين ، لم يكن لتخصيص الكافر بالذكر في حال تقبيح أمرهم معنى ، كها أن مفهومه

(1) - ابن الأثير ، مجد الدين أبو السعادات المبارك بن محمد بن محمد الشيباني الجزري ( ت ج 7 هـ ) ، النهاية في غريب الحديث والأثر ، تحقيق طاهر أحمد الزاوي ومحمود محمد الطناحي ، المكتبة العلمية ،

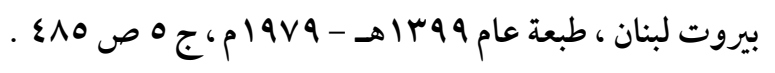

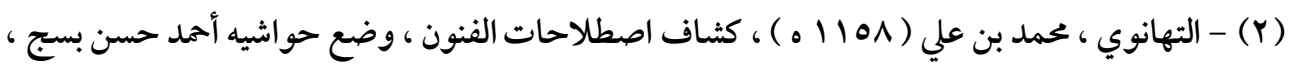

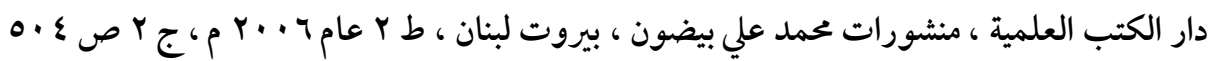

(r) - محمد أحمد الحاج وبسام علي العموش ، قاموس العقيدة ، الأكاديميون للنشر والتوزيع ، عمان الأردن ،

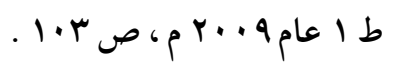

( ) - القرطبي ، أبو عبد الله محمد بن أحمد الأنصاري ، الجامع لأحكام القرآن ، تحقيق سالم مصطفى البدري

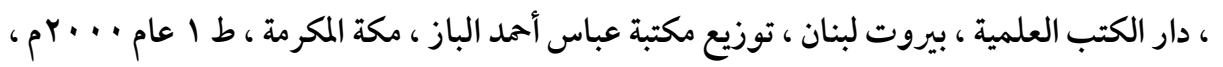

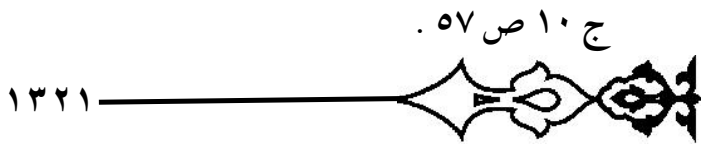



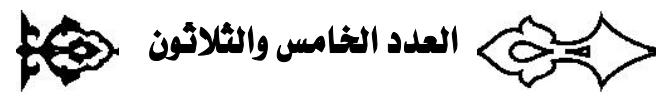

يدل على انتفاع المؤمنين بها ، يقول الشنقيطي : " فيه أن الكفار لا تنفعهم شفاعة الشافعين ،

كما أن فيه إثبات الشفاعة للشافعين ، ومفهوم كونها لا تنفع الكفار أنها تنفع غيرهم " (1) ، فالآية تتحدث عن نفع الثفاعة أو عدم نفعها لا في إثباتها أو نفيها ، فهي ثابتة بالأدلة الكثيرة . وقد ورد لفظ الثفاعة في مواضع كثيرة من كتاب الله تعالى ، ومعظم الآيات الواردة في ذلك تتعلق ببيان شروطها ، ونفيها عن غير مستحقيها ، وستأتي الإشارة إلى المزيد منها عند بيان شروط الشفاعة بإذنه تعالى . r - عن أنس بن مالك رضي الله عنه : أن رسول الله صلى الله عليه وسلم قال : " لكل نبي دعوة قد دعا بها فاستجيب ، فجعلت دعوتي شفاعة لأمتي يوم القيامة " (r) . يقول شيخ الإسلام ابن تيمية رحمه الله : " قد ثبت بالسنة المستفيضة بل المتواترة واتفاق الأمة : أن نبينا صلى الله عليه وسلم الشافع المثفع " (r) ، فإذا أثبتنا شفاعته صلى الله عليه وسلم ؛ دل ذلك على أن شفاعة غيره كذلك بشكل عام ثابتة ، فها ورد من نصوص الكتاب والسنة ما يثبت لأحد من شفاعة أثبتناه ، وما ورد من نفي نفيناه ، ولذلك وضع العلماء للشفاعة شروطاً، وقسموها أنواعاً. قال أبو بكر بن خزيمة رحمه الله : " وأخر نبينا صلى الله عليه وسلم دعوته ليجعلها شفاعة

(1) - الشنقيطي ، محمد الأمين بن محمد المختار الجكني ( ت بهوبا ه ) ، أضواء البيان في إيضاح القرآن بالقرآن ، التتمة من عمل تلميذه عطية محمد سالم ، دار الحديث ، القاهرة مصر ، الناشر مكتبة العلوم

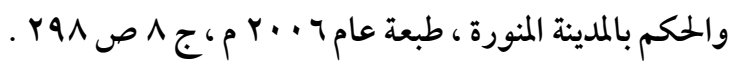

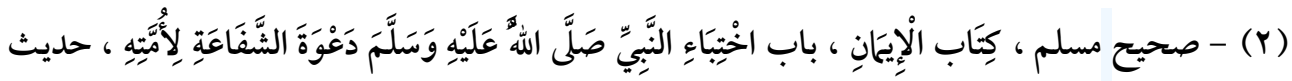

$$
\text { رقم } 191
$$

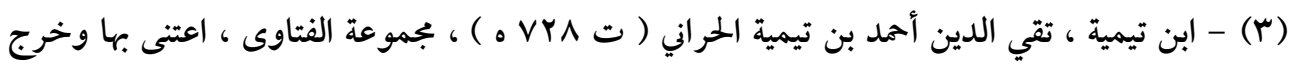

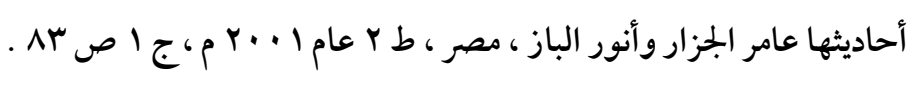

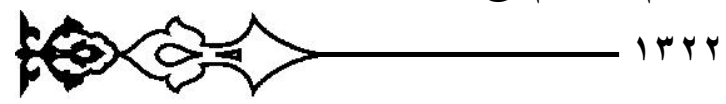




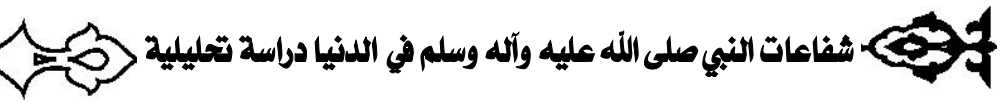

لأمته ، لفضل شفقته ورحته ور أفته بأمته ، فجزى الله نبينا ححمداً أفضل مما جزى رسولاً عمن

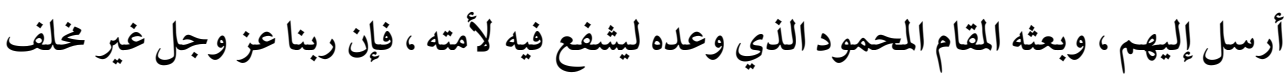
وعده ، ومنجز نبيه صلى الله عليه وسلم ما أخر من مسألته في الدنيا وقت شفاعته يوم القيامة

r-عن أبي هريرة رضي الله عنه قال : قال رسول الله صلى الله عليه وسلم : " أنا سيد ولد آدم

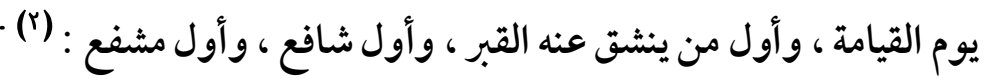

\section{المطلب الثالث : شروطها وأركانها وأسبابها}

إنّ التدبر في آيات القرآن الكريم يوّضح أنّ الله سبحانه وتعالى لم يجدد في الآيات القرآية الشريفة وفي آيات الشفاعة اسم أحد من الشافعين ، لكن القرآن الكريم أشار إلى بجموعة من الصفات التي إن توفرت في أحد : فهو من الشفعاء ، بعد أن يأذن الله له في ذلك .

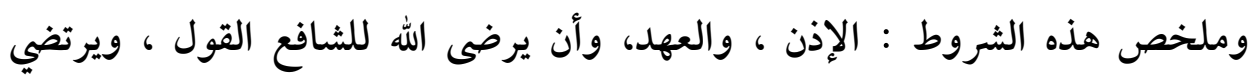

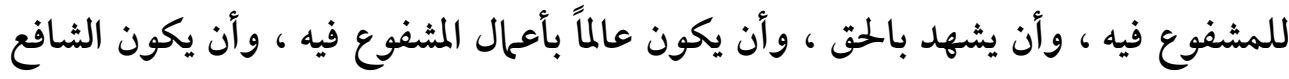

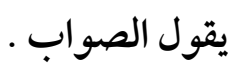

وأما أركانها فهي : الثافع ، والمشفوع له ، والمشفوع عنده ، والمشفوع فيه ( موضوع الشفاعة ) ، وسوف أقوم إن شاء الله في هذا البحث بتطبيق هذه الأركان على شفاعاته صلى الله

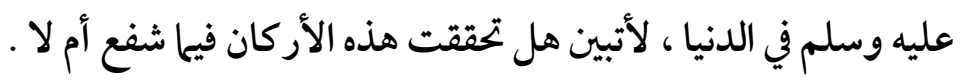

(1) - ابن خزيمة ، أبو بكر كمد بن إسحاق ( ت الب ه ه ) ، التوحيد ، قدم له ووضع حواشيه وعلق عليه

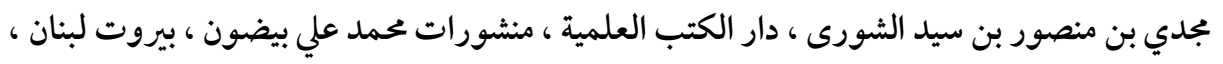
b ا عام

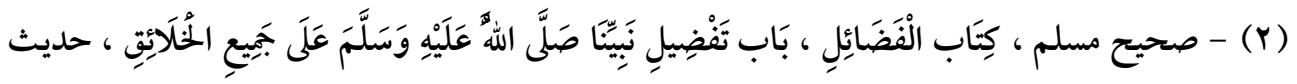




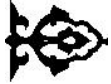

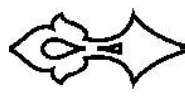

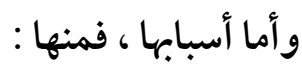

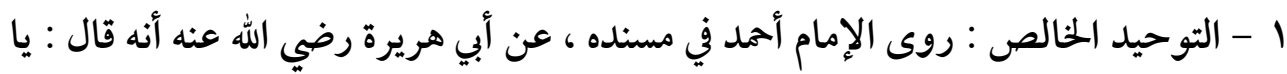
رسول الله ماذا رد إليك ربك عز وجل في الشفاعة ؟ قال : " لقد ظنتت لتكونن أول من

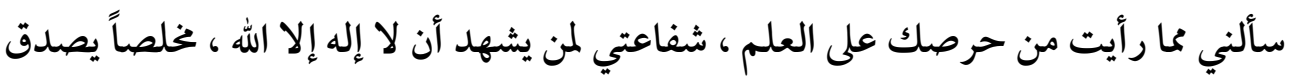
قلبه لسانه ، ولسانه قلبه " فأسعد الناس بشفاعته صلى الله عليه وسلم أكملهم إخلاصاً لله

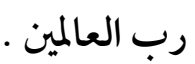

قال شيخ الإسلام ابن تيمية رحمه الله تعالى : " سبب الشفاعة : توحيد الله ، وإخلاص

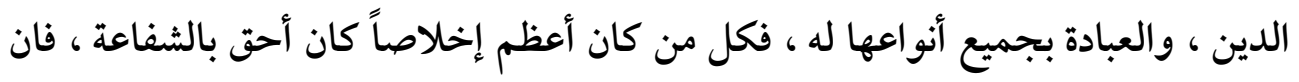

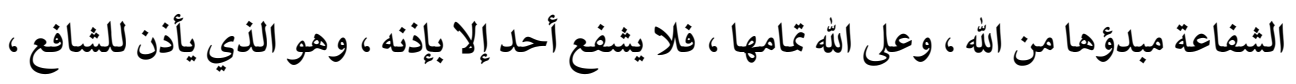

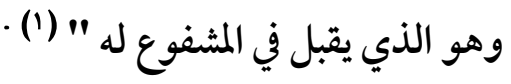

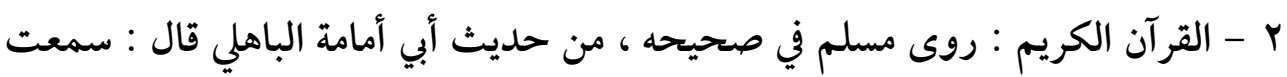

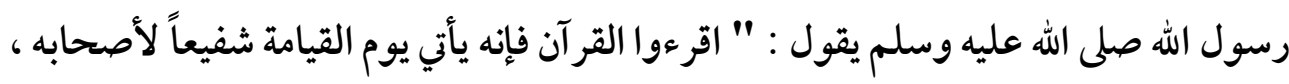

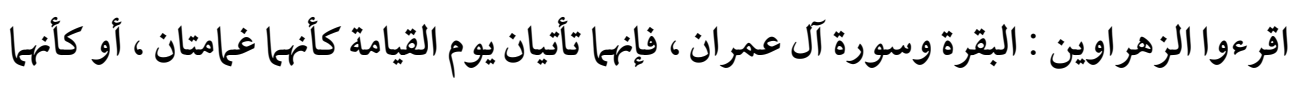

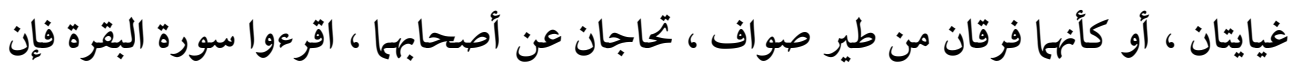
أخذها بركة ، وتركها حسرة ، ولا تسطيعها البطلة " ، قال معاوية: بلغني أن البطلة (السحرة) (ن) (ن)

ومن ذلك سورة تبارك: روى الإمام أحمد وغيره، عن أبي هريرة ، عن النبي صلى الله عليه

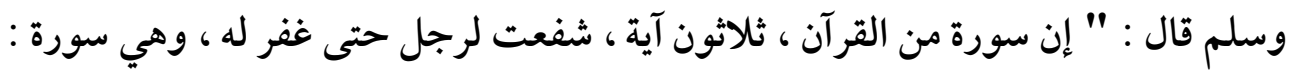

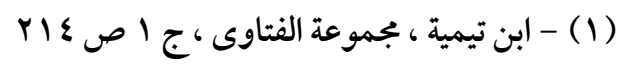

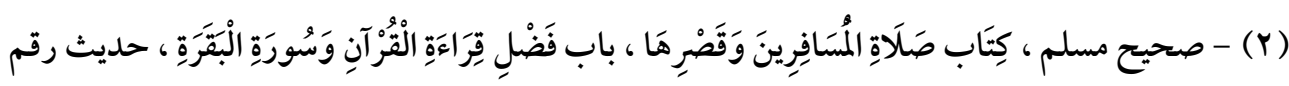




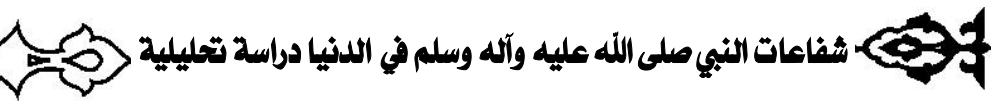

(تبارك الذي بيده الملك) " (1) (1) - (1)

r - الصيام: روى الإمام أحمد في المسند ، عن عبد الله بن عمرو ، أن رسول الله صلى الله عليه وسلم قال : : الصيام والقر آن يشفعان للعبد يوم القيامة ، يقول الصيام : أي رب منعته الطعام والثهوات بالنهار ، فشفعني فيه ، ويقول القرآن : منعته النوم بالليل ، فشفعني فيه ، قال :

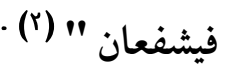

ع - سكنى المدينة والموت بها : روى مسلم في صحيحه ، عن أبي سعيد مولى المهري ، أنه جاء أبا سعيد الخدري ليالي الحرة ، فاستثاره في الجلاء من المدينة ، وشكا إليه أسعاره وكثرة عياله ، وأخبره أن لا صبر له على جهد المدينة ولأوائها ، فقال له : ويحك ، لا آمرك بذلك ، إني سمعت رسول الله صلى الله عليه وسلم يقول : " لا يصبر أحد على لأوائها ؛ فيموت إلا كنت له شفيعاً أو شهيداً يوم القيامة ، إذا كان مسلماً " (r) . ه - الصلاة على النبي صلى الله عليه وسلم وطلب الوسيلة له : روى البخاري ومسلم في الصحيحين ، من حديث عبداله بن عمرو بن العاص رضي الله عنه ، أنه سمع النبي صلى الله عليه وسلم يقول : " إذا سمعتم المؤذن ؛ فقولوا مثل ما يقول ، ثم صلوا علي ، فإنه من صلى علي صلاة صلى الله عليه بها عشراً ، ثم سلوا الله لي الوسيلة ، فإنها منزلة في الجنة لا تنبغي إلا

(1) - مسند أحمد ، بَاقِي مُسنَكِد المُكْثِرينَ ، إن سورة من القرآن ثلاثون آية شفعت لرجل حتى غفر له

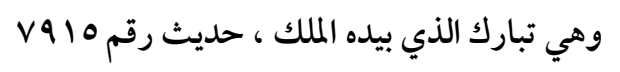

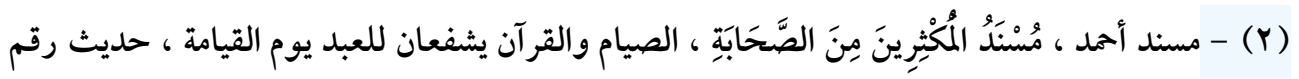

(r) - صحيح مسلم، كِكَاب الحُجِّ ، باب اللهم بارك لنا في صاعنا ومدنا واجعل مع البركة بركتين ، حديث 
لعبد من عباد الله ، وأرجو أن أكون أنا هو ، فمن سأل الله لي الوسيلة حلت له الثفاعة " (1) . 1 - أن يصلي عليه مائة من المسلمين: روى مسلم في صحيحه من حديث عائشة رضي الله عنها ، عن النبي صلى الله عليه وسلم قال : " ما من ميت تصلي عليه أمة من المسلمين ، يبلغون مائة كلهم

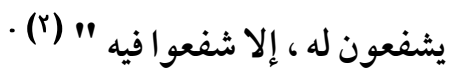
V - كثرة الصلاة: روى مسلم في صحيحه، من حديث ربيعه بن كعب الأسلمي قال: كنت أبيت مع رسول الله صلى الله عليه وسلم ، فأتيته بوضوئه وحاجته ، فقال لي : سل ! فقلت: أسألك مر افقتك في الجنة، قال: أو غير ذلك؟ قلت : هو ذاك، قال : " فأعني على نفسك بكثرة السجود " (r) .

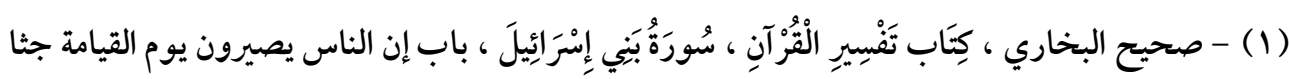

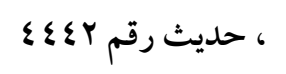

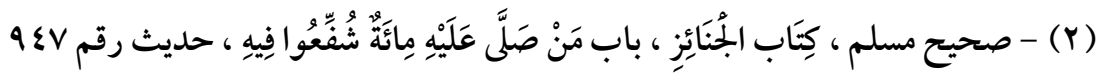

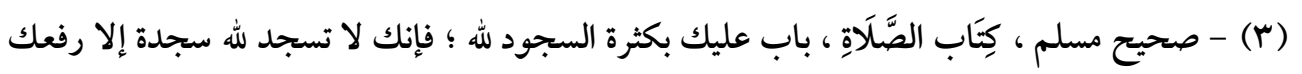

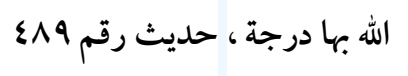




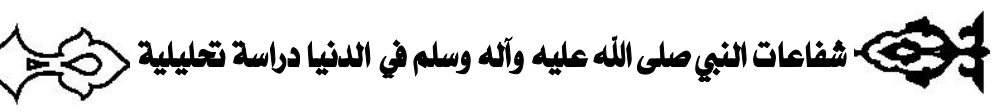

\section{المبحث الثاني : شُفاعات النبي صلى الله عليه وآله وسلم للعالمين.}

المطاب الأول : شفاعته صلى الله عليه وآله وسلم للكفار.

1 - أشفاعته لثمامة بن أثال :

عن أبي هريرة رضي الله عنه قال : " بعث النبي صلى الله عليه وسلم خيلا قبل نجد ؛ فجاءت برجل من بني حنيفة يقال له ثمامة بن أثال ، فربطوه بسارية من سواري المسجد ، فخرج إليه النبي صلى الله عليه وسلم فقال : ما عندك يا ثمامة؟ ، فقال : عندي خير يا محمد ، إن تقتلني تقتل ذا دم ، وإن تنعم تنعم على شاكر ، وإن كنت تريد المال فسل منه ما شئت ، فترك حتى كان الغد ، ثم قال له : ما عندك يا ثمامة ؟ ، قال : ما قلت لك ، إن تنعم تنعم على شاكر ، فتر كه حتى كان بعد الغد ، فقال : ما عندك يا ثمامة ؟ ، فقال : عندي ما قلت لك ، فقال : أطلقوا ثمامة ، فانطلق إلى نجل قريب من المسجد فاغتسل ، ثم دخل المسجد ، فقال : أشهد أن لا إله إلا الله ، وأشهد أن محمدا رسول الله ، يا محمد ، والله ما كان على الأرض وجه أله أبغض إلي من وجهك ، فقد أصبح وجهك أحب الوجوه إلي ، والله ما كان من دين أبغض إلي من دينك ، فأصبح دينك أحب الدين إلي ، والله ما كان من بلد أبغض إلي من بلدك ، فأصبح بلدك أحب البلاد إلي ، وإن خيلك أخذتني ، وأنا أريد العمرة ، فماذا ترى ؟ فبشره رسول الله صلى الله عليه وسلم، وأمره أن يعتمر، فلما قدم مكة، قال له قائل: صبوت؟ قال: لا،ولكن أسلمت مع محمد رسول الله صلى الله عليه وسلم، ولا والله لا يأتيكم من اليامة حبة حنطة حتى يأذن فيها النبي صلى الله عليه وسلم " (1). وجه الدلالة: - 20 - n حَثَّ الشَّرعُ على العَفِ عِندَ المَقدرَةِ، والإحسانِ إلى النَّاسِ ؛ِلِنَّها تُوصلُ إلى كَسبِ القُلوبِ

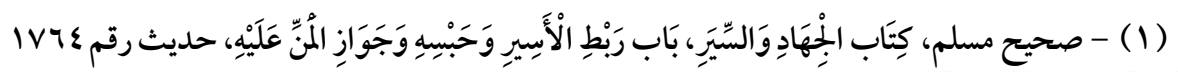




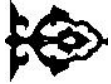

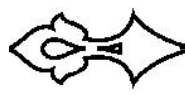

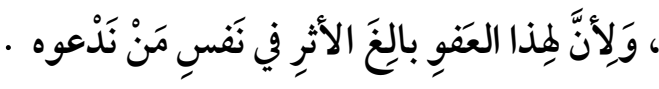

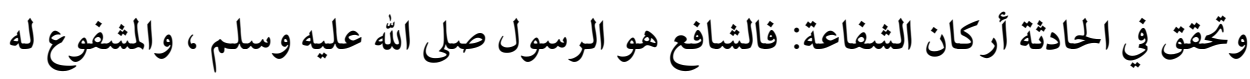

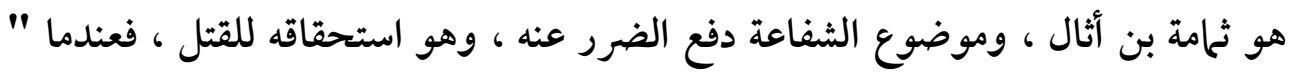

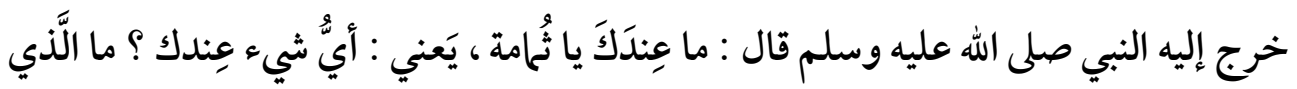

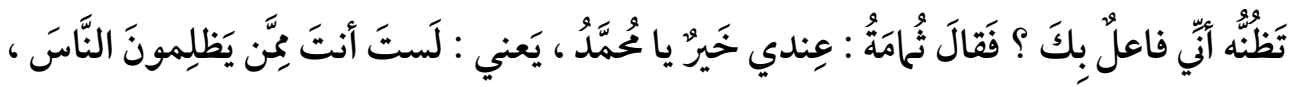

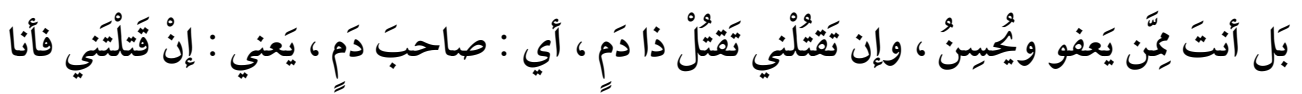

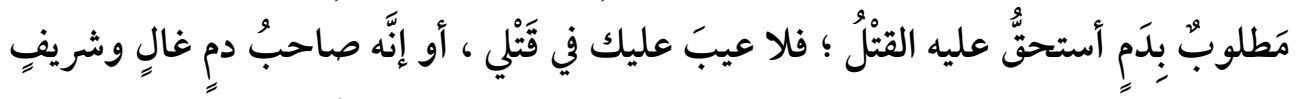

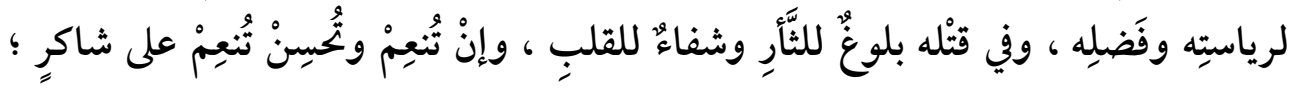

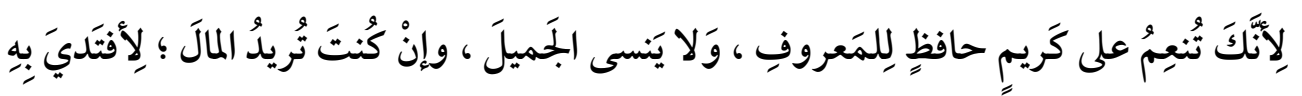

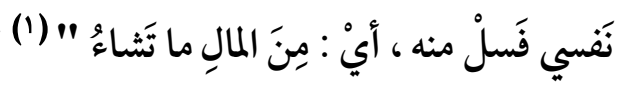
والنبي صلى الله عليه وسلم شفع له من القتل، وأحسن إليه حتى يلين قلبه ، ويفتح مغاليق

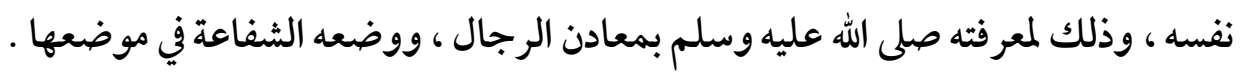
وهذا الفعل منه صلى الله عليه وسلم تحقيق لمقاصد الدعوة الإسلامية، والجهاد في سبيل الله؛ إذ ليس المقصود من الجهاد إراقة الدماء، والمقصود من الدعوة إقامة الحجة فحسب ، وإنما المقصود حفظ النفوس ، والاهتداء إلى الحق والالتزام به (r) Y - بفاعته للرجل الذي أراد قتله :

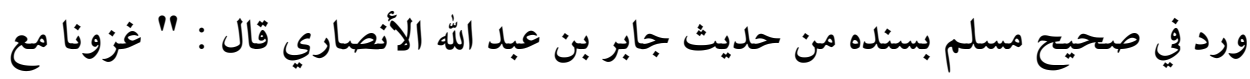

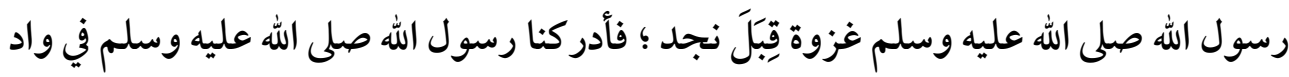

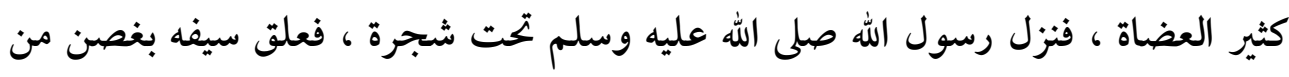

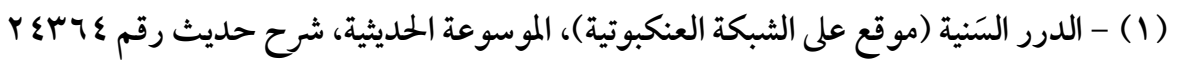
(Y) - انظر : المرجع السابق. 


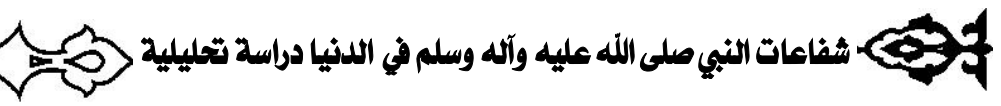

أغصانها ، قال : وتفرق الناس في الوادي يستظلون بالشجر ، قال : فقال رسول الله صلى الله عليه وسلم : إن رجلاً أتاني وأنا نائم ، فأخذ السيف ، فاستيقظت وهو قائم على رأسي ، فلم أشعر وإلا السيف صلتا في يده ، فقال لي : من يمنعك مني ؟ قال : قلت : الله ! ثم قال في الثانية : من يمنعك مني ؟ قال : قلت : الله ! قال : فشام السيف (1) ، فها هو ذا جالس ، ثم لم

يعرض له رسول الله صلى الله عليه وسلم " (ז) . وجه الدلالة

أن النبي صلى الله عليه وسلم عفا عنه بعدما أراد قتله ، فلما جاء رجلٌ مِن المثرِ كين وسَيْفُه

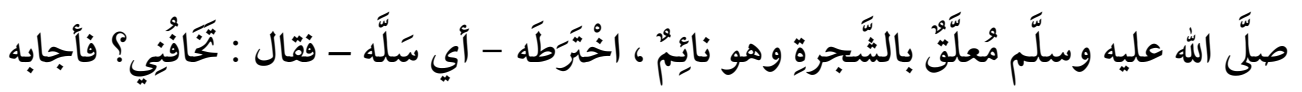

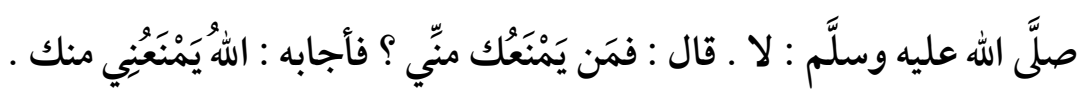

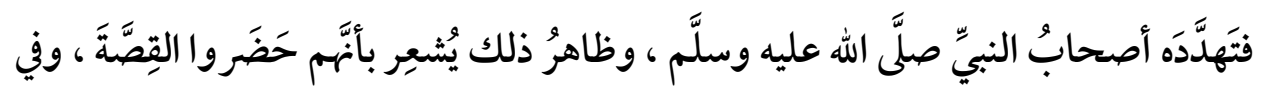
رواية : أن السيف سقط من يده ، وهي معجزة ظاهرة للنبي صلى الله عليه وسلم . ولما كان ذلك الأمر لم يفعل النبي صلى الله عليه وسلم كما فعل الرجل ، بل عفا عنه ، وخلى سبيله ، فالشافع هو النبي صلى الله عليه وسلم ، والمثفوع له رجل من المثركين ، وموضوع

الشفاعة أنه لم يوقع الضرر بالمشرك ، وهو معاملته بالمثل وقتله (r) . r - شفاعته صلى الله عليه وسلم لأهل الطائف: ورد في صحيح مسلم من حديث عروة بن الزبير ، أن عائشة رضي الله عنها زوج النبي

(1) - شام السيف: أي أغمده وأخذه ذات الشمال، انظر : الفيروز آبادي، القاموس المحيط، ص هAV، مادة شأم . شأم

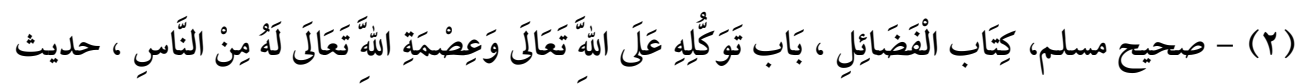

$$
\text { رقم }
$$

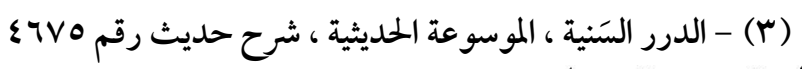




\section{5}

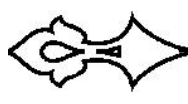

صلى الله عليه وسلم حدثثه قالت : " يا رسولَ اللهِ ، هل أتى عليك يومُ كان أشدَّ من يومِ أُحْدِ

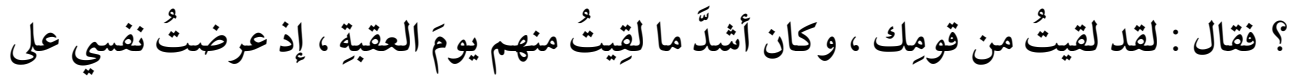

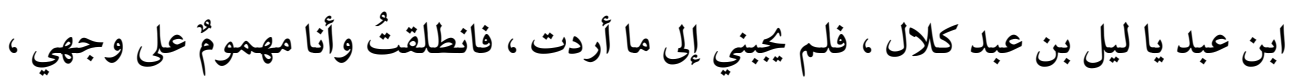

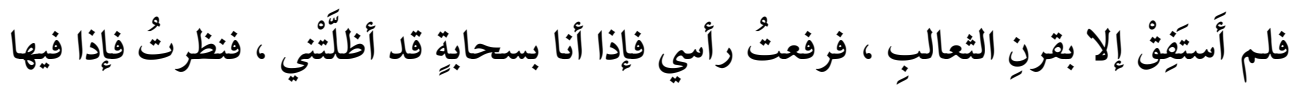

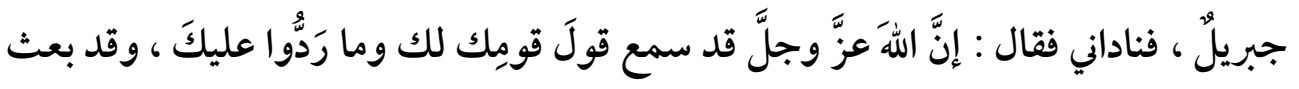

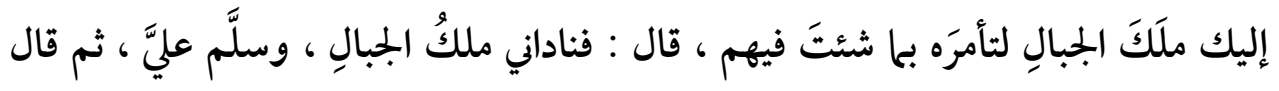

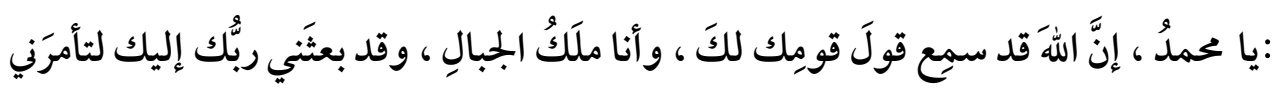

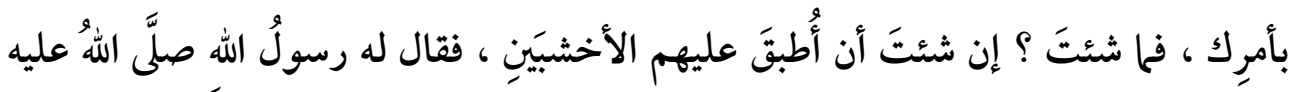

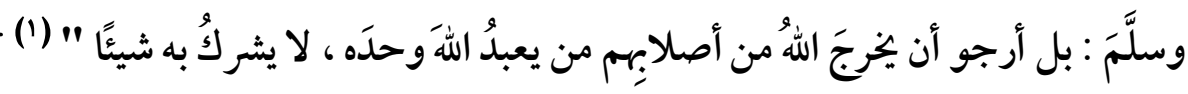
وجه الدلالة

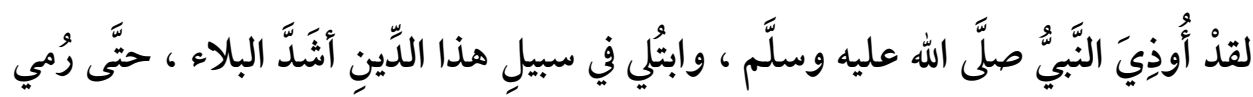

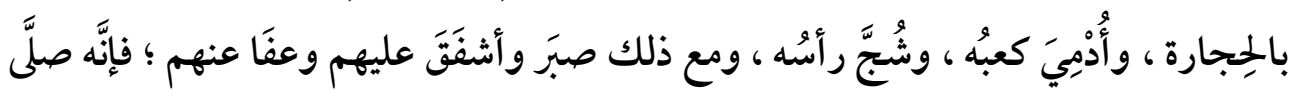

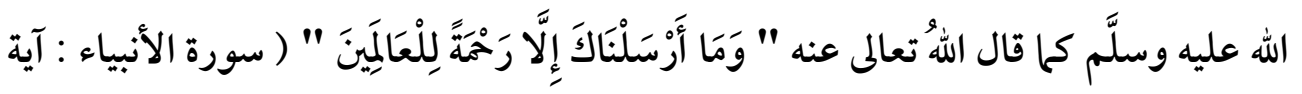

وقد تحققت الشفاعة في هذه الحادثة ، فالشافع هو النبي صلى الله عليه وسلم ، والمشفوع لمم

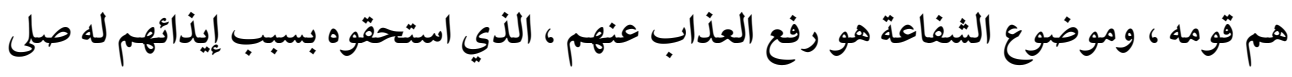

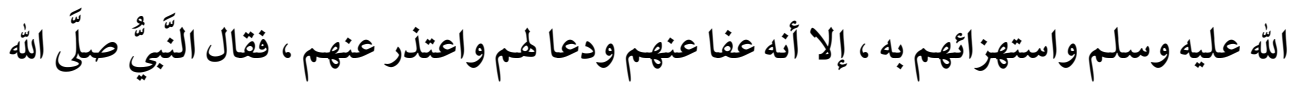

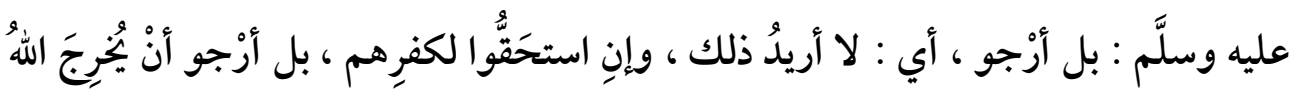

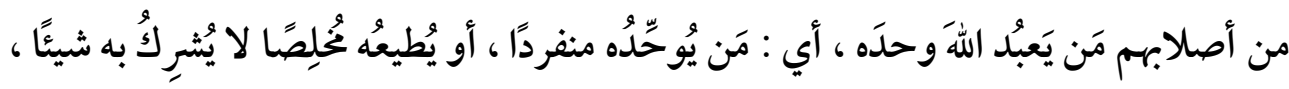

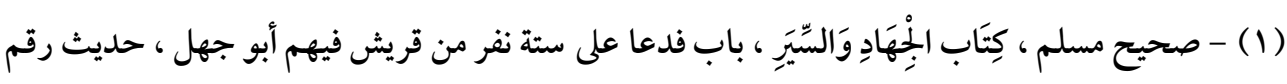
1890

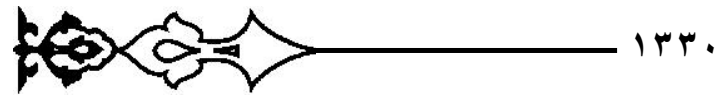




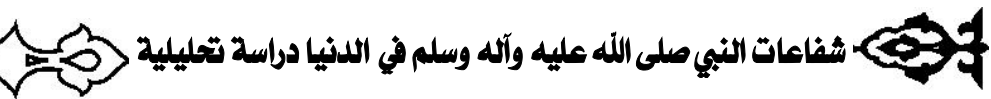

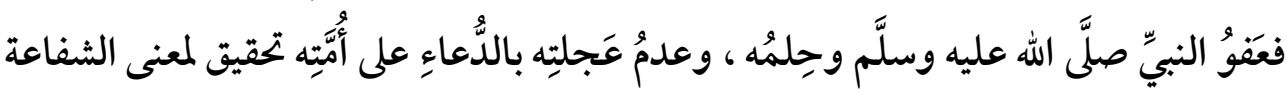

في الدنيا (1)

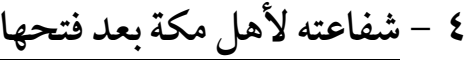

روى أبو داوود بسنده " أنّ النبيَّ صلى الله عليه وسلم لما دخل مكة ، سرّح الزبير بن العوام

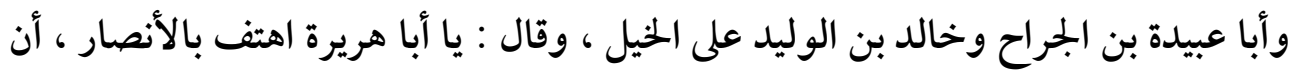

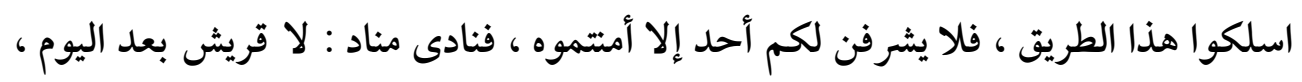

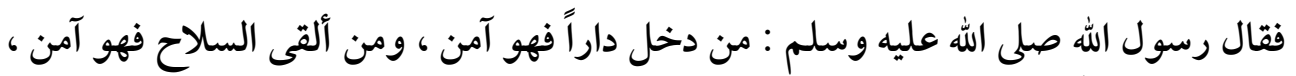
وعمد صناديد قريش فدخلوا الكعبة ، فغص بهم وطاف النبي صلى الله عليه وسلم، وصلى خلف المقام ، ثم أخذ بجنبتي الباب ، فخرجوا فبايعوا النبي صلى الله عليه وسلم على الإسلام

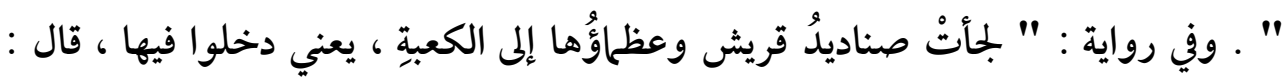

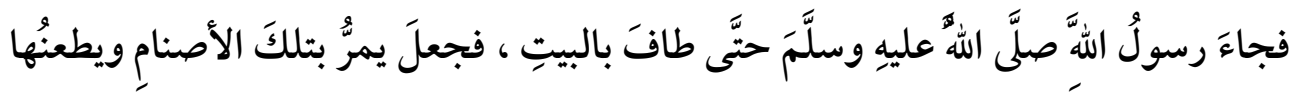

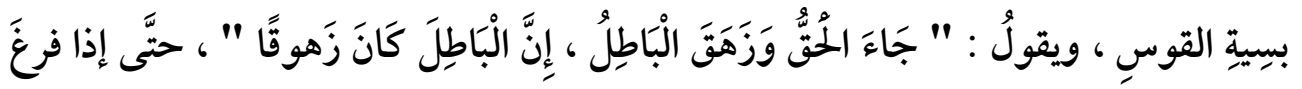

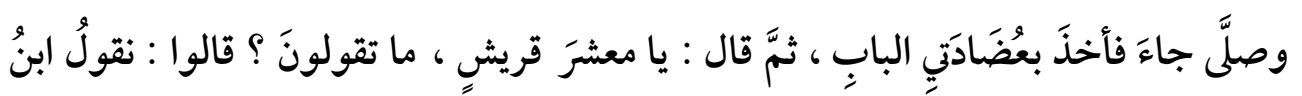

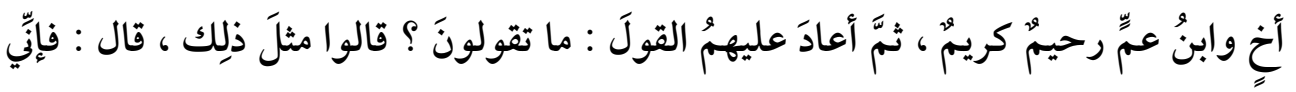

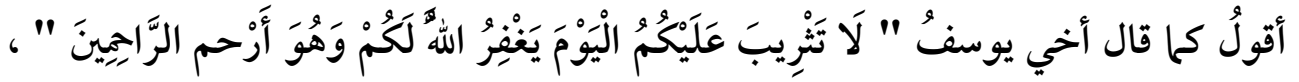

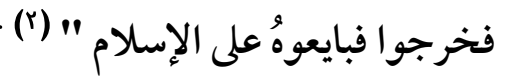

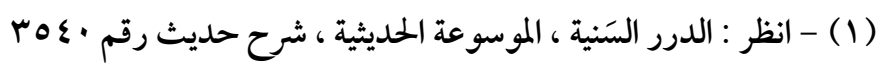

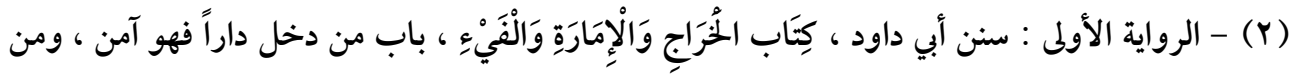

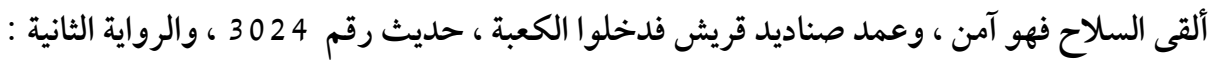

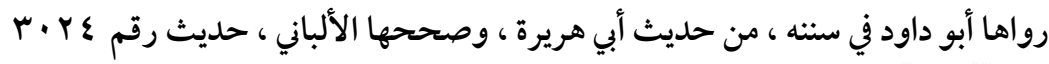


وجه الدلالة

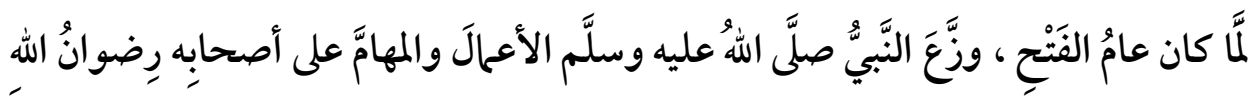

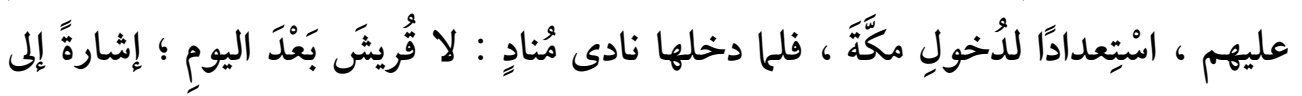

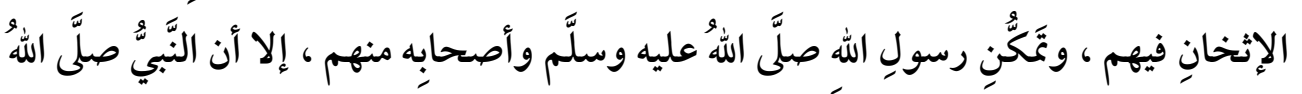

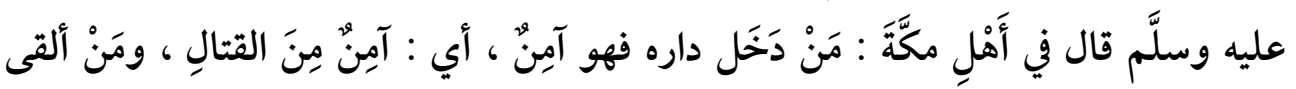

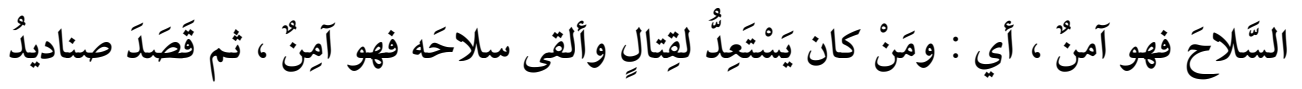

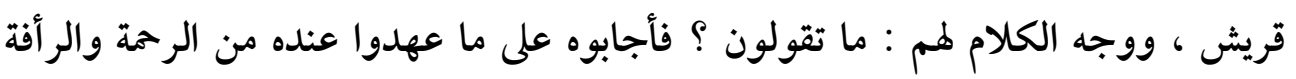

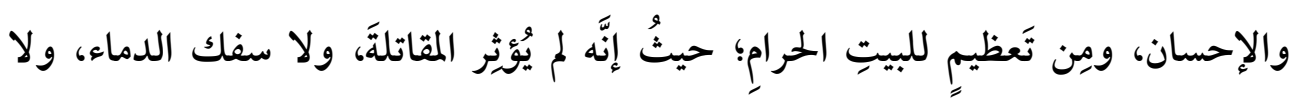

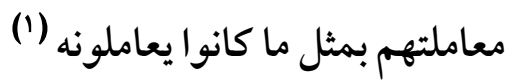
فكان الفتح فتح مرحمة لا فتح ملحمة، وتحققت أركان الشفاعة، فالشافع هو النبي صلى الله

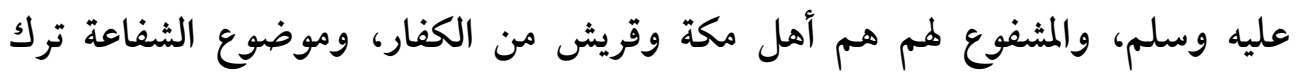
القصاص منهم ومعاملتهم بالمثل على ما أبدوا من شقاق ونزاع وحر ابة له هـ ، ونقضهم العهد والصلح معهم . المطلب الثاني : شفاعته صلى الله عليه وآله وسلم للعيوانات. 1 - شفاعته للجمل:

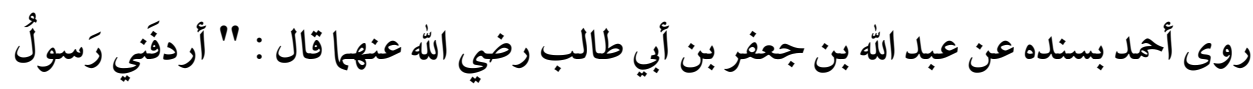

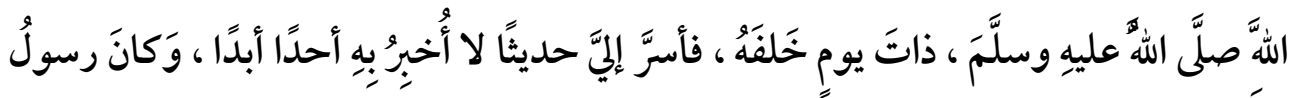

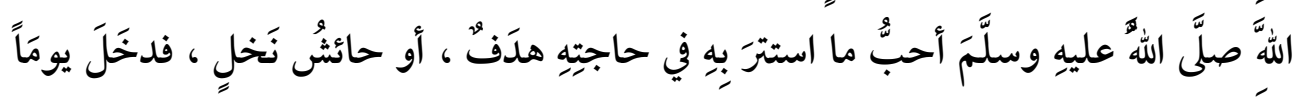

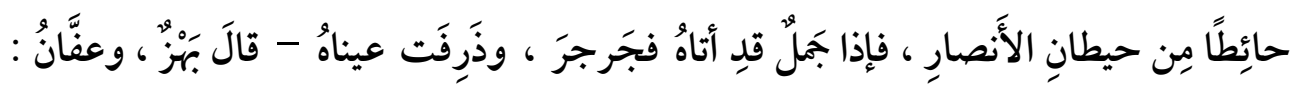

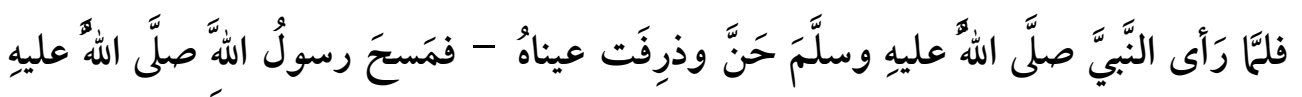

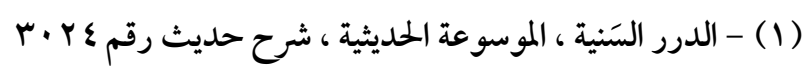

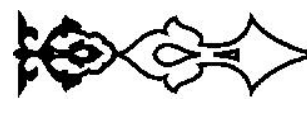




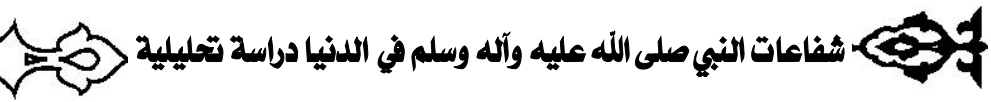

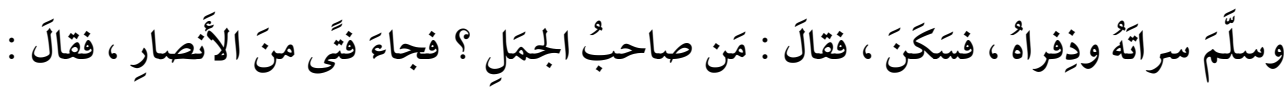

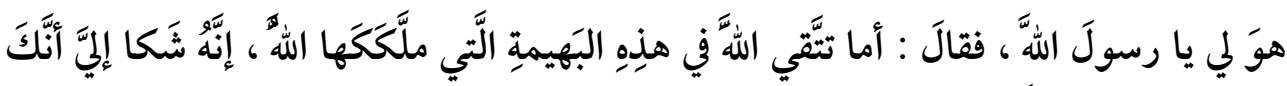

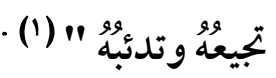

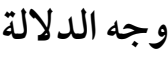

مجلة

كلية

في هذه الحادثة تتمثل الرحمة والر أفة والرفق بالحيوان منه صلى الله عليه وسلم ، والرَّفقِقُ لا لا

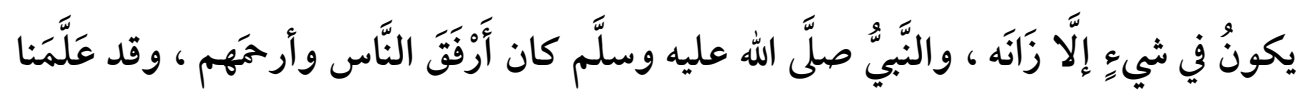

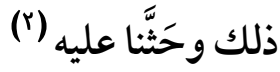

ورحمةُ النَّبِّ صلَّلَ الله عليه وسلَّمَ بالحَيَوانِ هي من شفاعته للمخلوقات جميعاً ، فالشافع هو النبي صلى الله عليه وسلم ، والمشفوع له هو الجمل ، وموضوع الشفاعة أنه صلى الله عليه وسلم طلب من صاحب الجمل أن يخفف عنه في العمل ، ليدفع عنه المثقة والضرر .

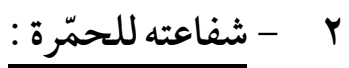

روى ابن الملقن عن عبدالله بن مسعود رضي الله عنه قال : " كنا مع رسولِ الله صلى اللهُ

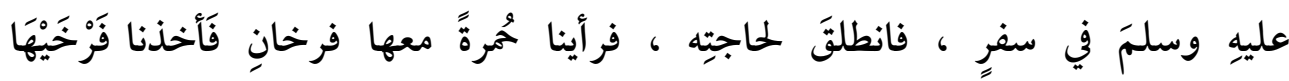

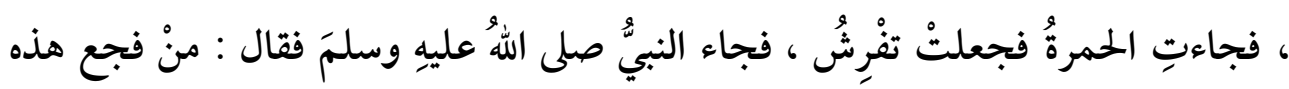

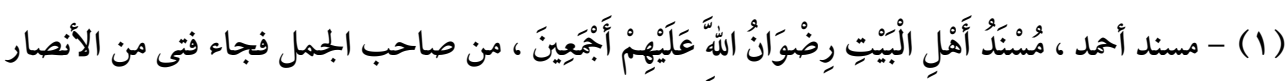

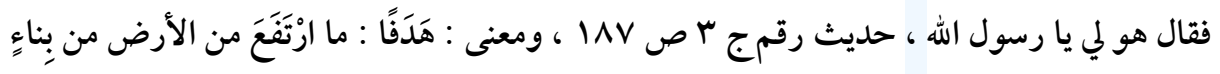

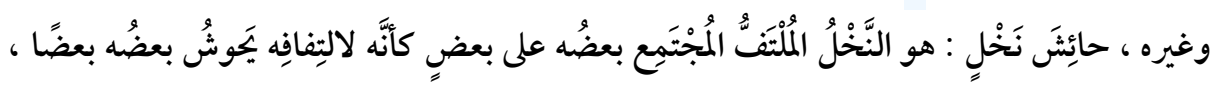

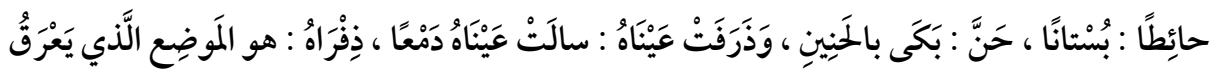

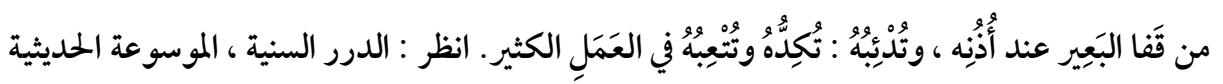

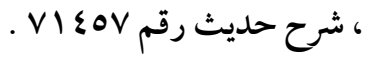

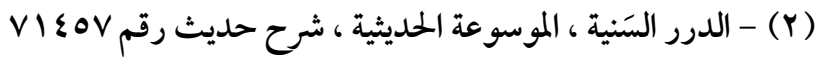




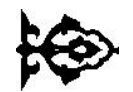

بولِدِهَا ، رُدُواُ وَلَدَهَا إليها ، ورأى قريةَ نملٍ قد حرقناها فقال : من حرق هذه ؟ قلنا : نَحن ،

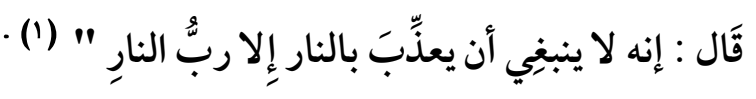
وجه الدلالة

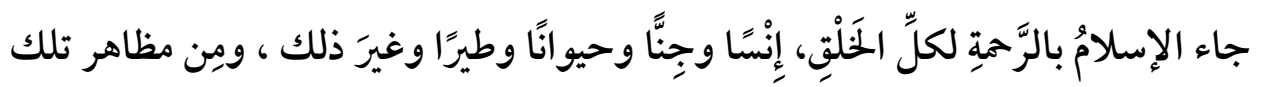

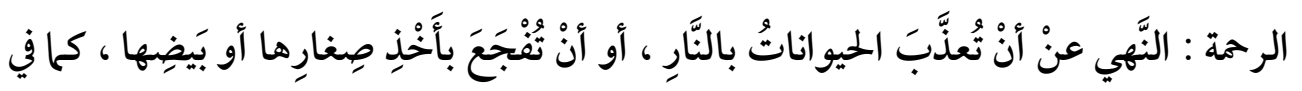

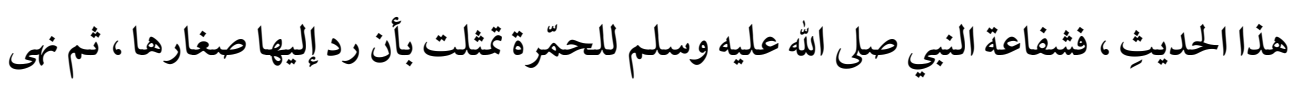
عن إحراق النمل أو الحيوانات على حد سواء ، لأنه أمر مختص بالله فقط (r) . وهذا من رحته صلى الله عليه وسلم، فالشافع هو النبي صلى الله عليه وسلم ، والمثفوع له هي الحمّة ، وموضوع الشفاعة إزالة الضرر الذي وقع لها بأخذ صغارها ، فأمرهم برد أولادها إليها ، وعدم ترويعها ، وإعطائها الأمان .

\section{المطلب الثالثة : شفاعته صلى الله عليه وآله وسلم للمسلمين.}

$$
1 \text { - شفاعته للمر أة السوداء التي كانت تقمّ المسجد: }
$$

روى الإمام مسلم بسنده، عن أبي هريرة رضي الله عنه قال : " " إنَّ امرأةً سوداءً

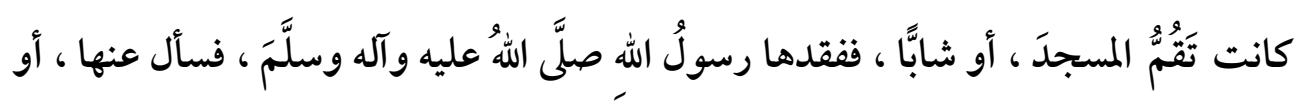

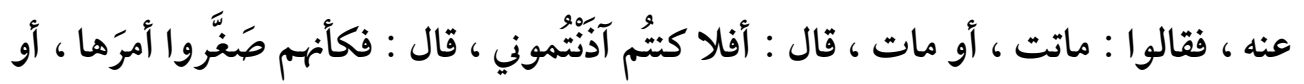

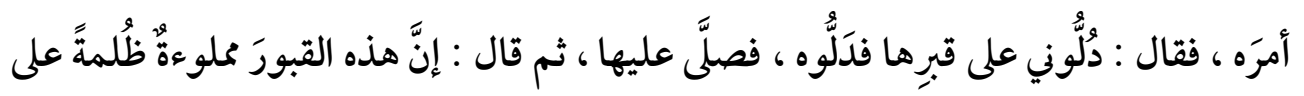

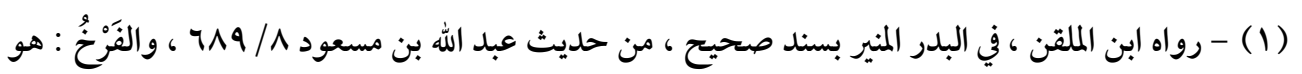

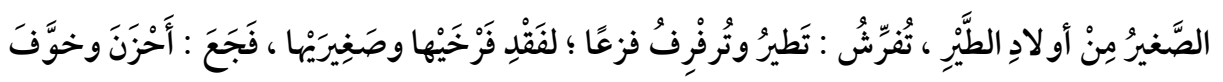

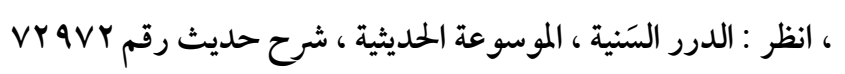

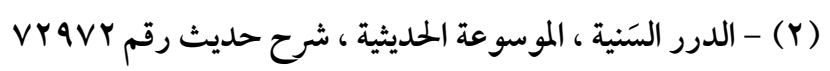




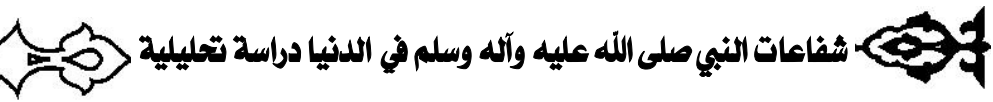

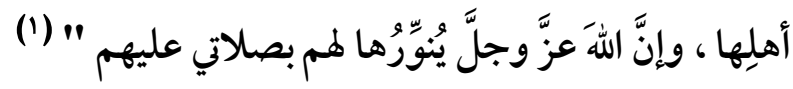

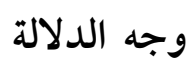

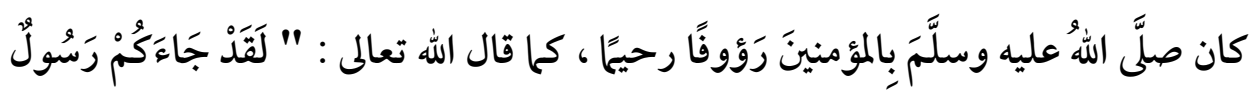

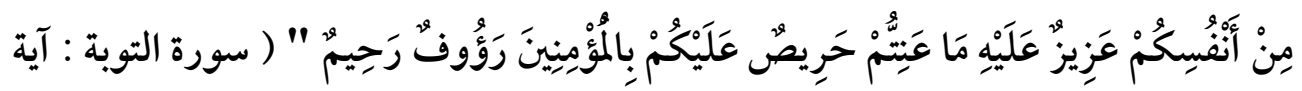

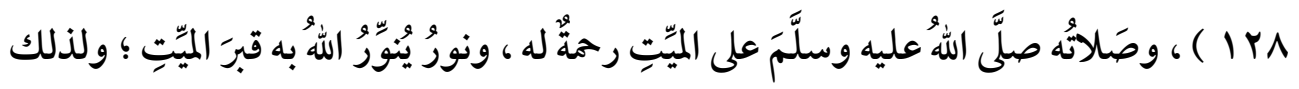

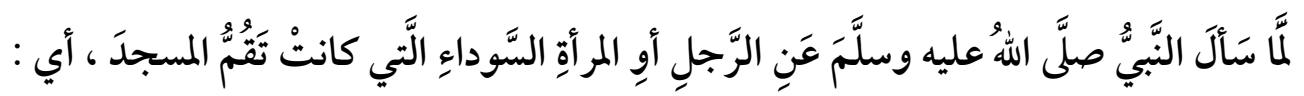

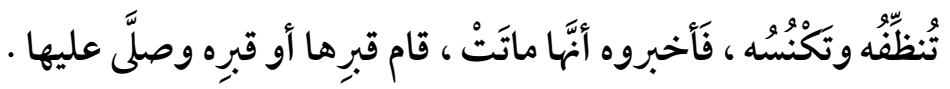
وفي صلاته تتحقق الشفاعة ، فإن كانت عليها ذنوب محيت بشفاعته ، وتقدمت هذه

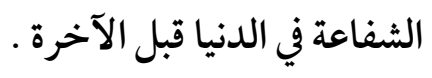

وهنا ، تحققت أركان الشفاعة ، فالشافع هو النبي صلى الله عليه وسلم ، والمشفوع له هي

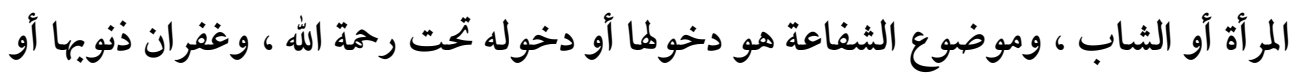
ذنوبه من خلال صلاته ودعائه صلى الله عليه وسلم لها أو له .

\section{r r - شفاعته لحاطب ابن أبي بلتعة :}

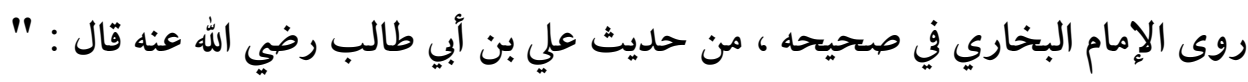

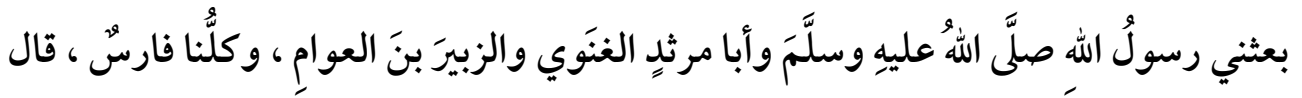

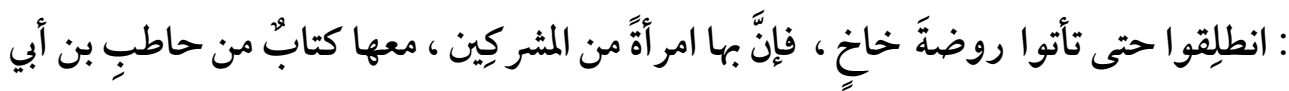

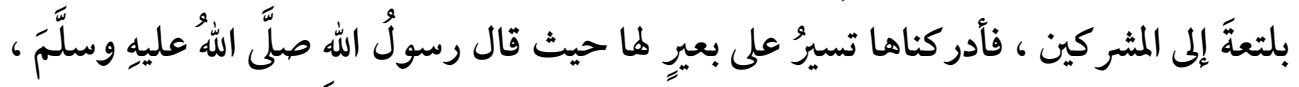

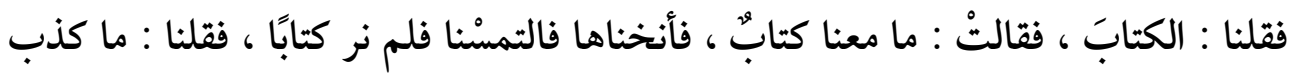

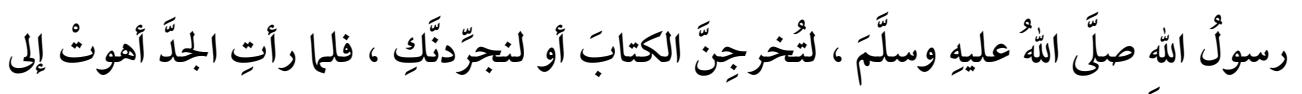

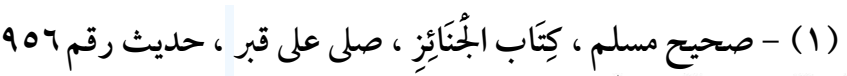




\section{0}

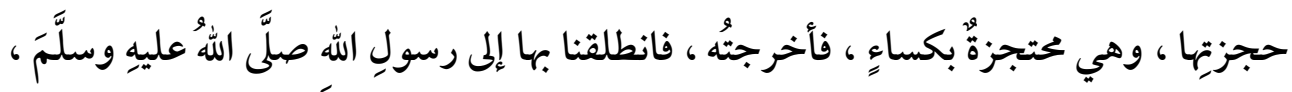

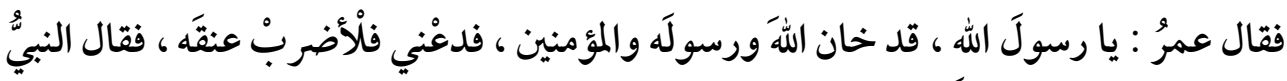

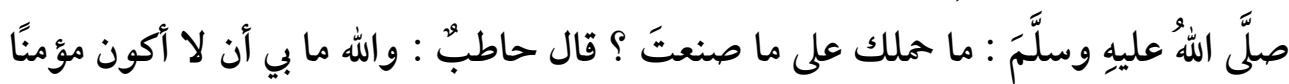

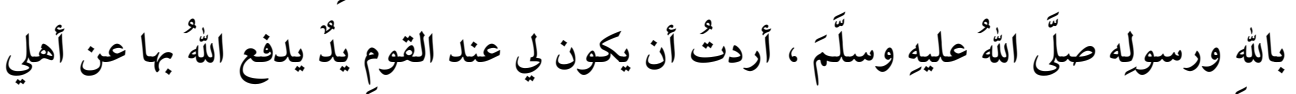

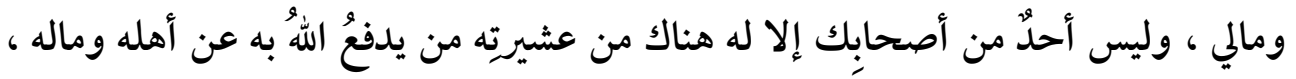

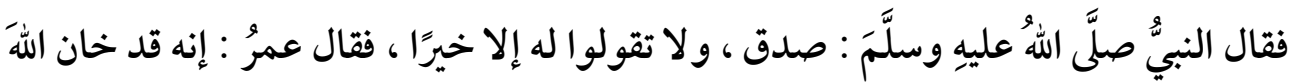

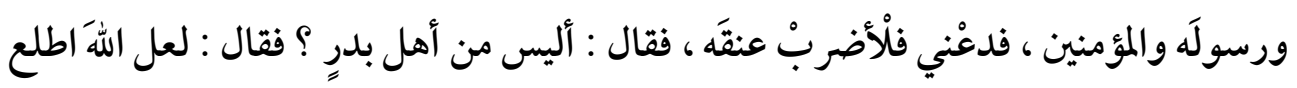

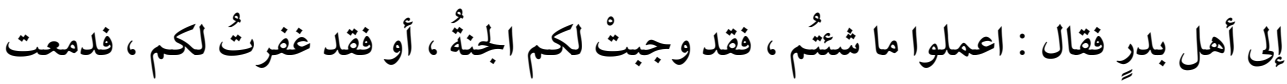

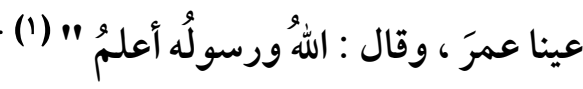

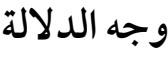
أن الصحابي الجليل حاطب قد فعل أمراً استحق عليه العقاب ، ولكن النبي صلى الله عليه

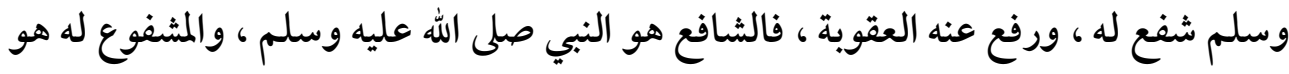
حاطب بن أبي بلتعة ، وموضوع الشفاعة رفع العقوبة عنه وإسقاطها ، وذلك لأنه من شهد

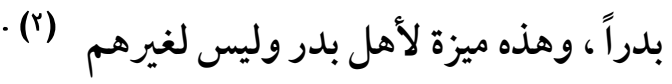

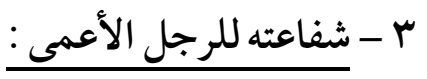
روى الترمذي من حديث عثلمان بن حنيف : " أن رجلاً ضرير البصر أتى رسول الله صلى

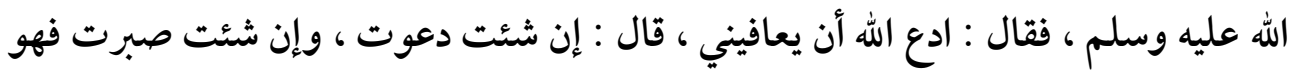

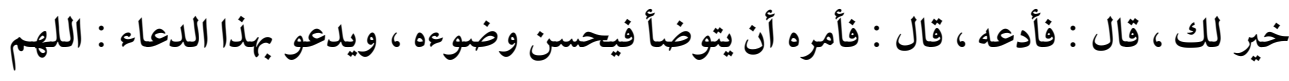

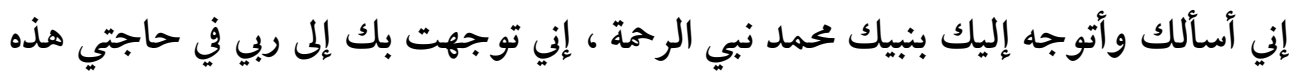

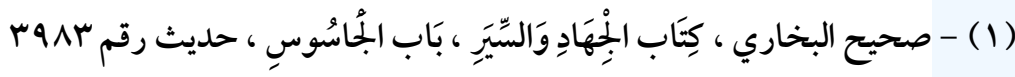

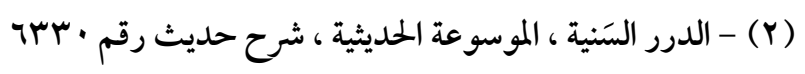




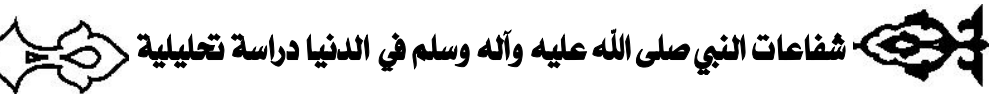

لتقضي لي ، اللهم فشفعه في " (1) -

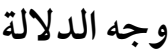

أن النبي صلى الله عليه وسلم وجه الرجل الأعمى إلى طلب الشفاعة منه صلى الله عليه

وسلم ، و معنى فشفعه في : أي اشفني بسببه ، وادفع عني ضر العمى لأجله و لمكانته عندك يا رب ، ولما فعل الرجل ذلك تحققت الشفاعة ، فرد الله إليه بصره ، فالشافع هو النبي صلى الله عليه وسلم ، والمشفوع له هو الرجل الأعمى ، وموضوع الشفاعة هو إزالة الضرر الذي وقع للرجل في بصره ، و وجلب منفعة الرؤية ونعمة الإبصار . ع - شفاعته للمر أة التي كانت تصرع :

ورى الإمام مسلم بسنده ، عن عطاء بن أبي رباح قال : قال لي ابنُ عباس : "

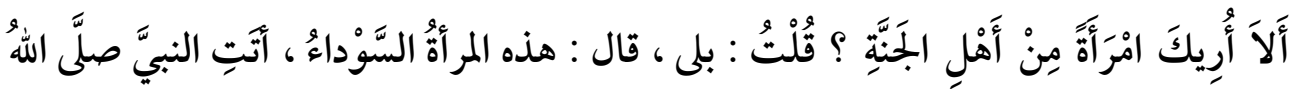

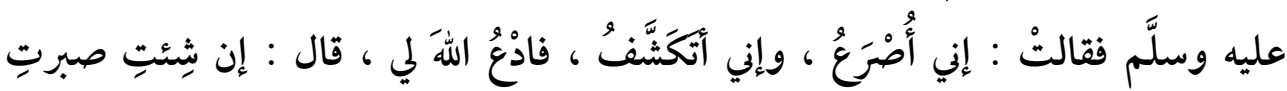

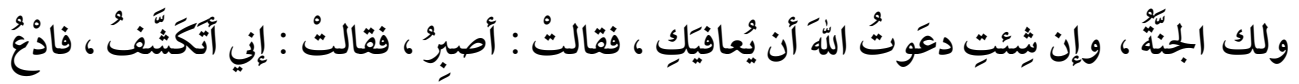

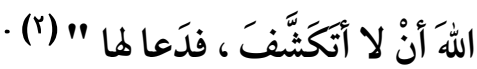

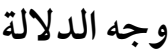

بيّن الحَديثِ بيانُ فضْلِ الصَّابرينَ على البلاءِ والمرَض ، وجزاءِ الله الذي ينتظوهم مُقابلَ

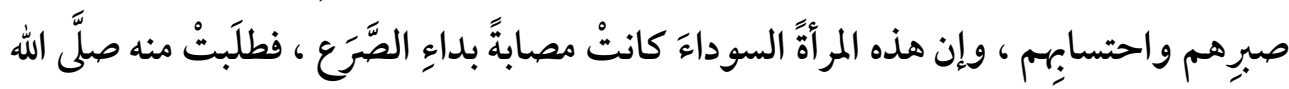
عليه وسلَّم أن يدعوَ لها ، فخيَّرها بين أنْ تَصِبرَ ويكون جزاؤها الجِنَّة ، وبَينَ أنْ يدعوَ لها

(1) - سنن الترمذي ، كِتَاب الدَّعَوَاتِ ، من قال أستغفر الله العظيم الذي لا إله إلا هو الحي القيوم وأتوب

$$
\text { إليه غفر له وإن كان فر من الزحف ، حديث رقم roV^ }
$$

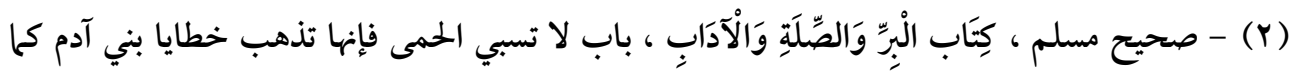

$$
\text { يذهب الكير خبث الحديد ، حديث رقم سVV }
$$




\section{0}

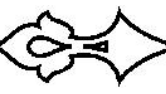

فيذهَبَ عنها المرضُ ، فاختارتِ الصَّبْرَ على المرض رجاءً الجُنَّة ، ولكنَّها طلَبتْ منه أنْ يدعوَ لها

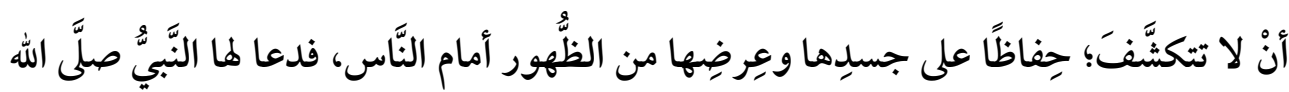

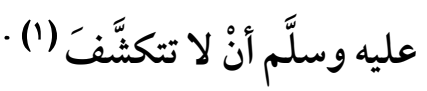
إن دعاء النبي صلى الله عليه وسلم مستجاب ، ودعاؤه لها تحقيق لمعنى الشفاعة الذي قررناه في بداية البحث ، فالشافع هو النبي صلى الله عليه وسلم ، والمثفوع له هو المرأة السوداء ،

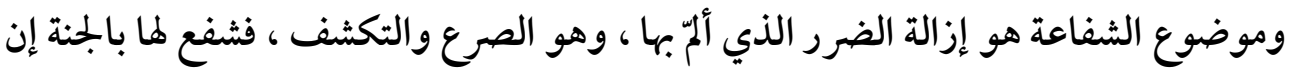

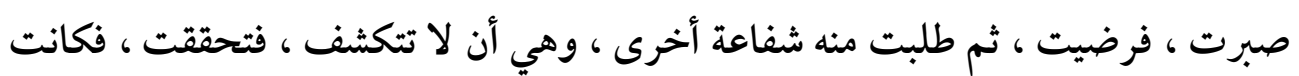

ورى الإمام البيهتي ، أنَّ جُجَيَبِيًا كان امرءاً من الأنصارِ ، وكان يدخلُ على النّّاءِ

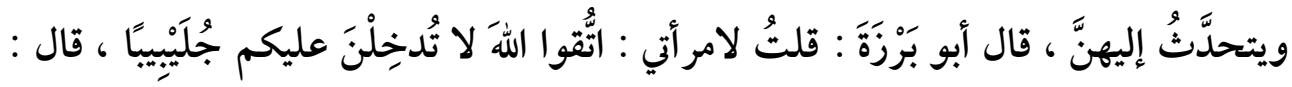

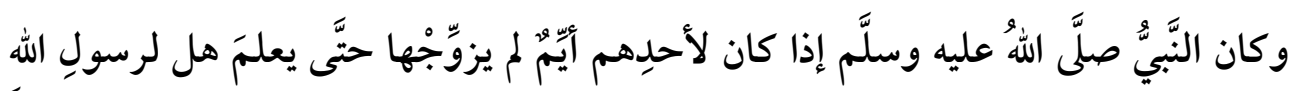

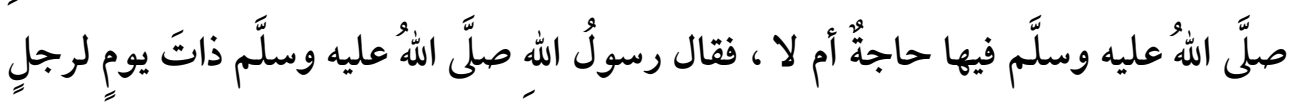

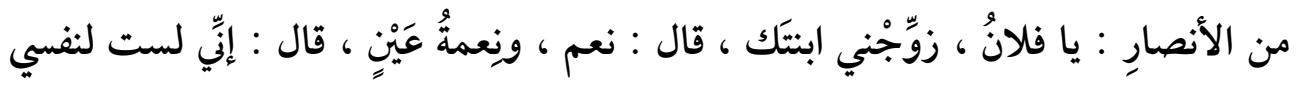

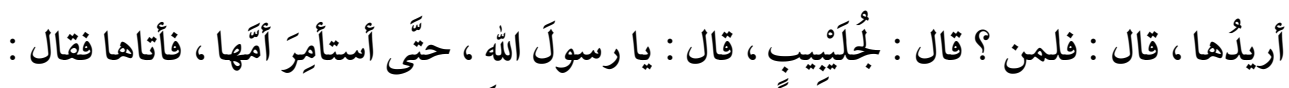

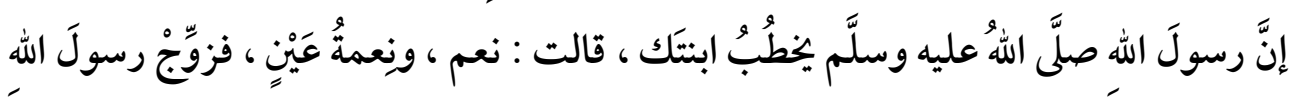

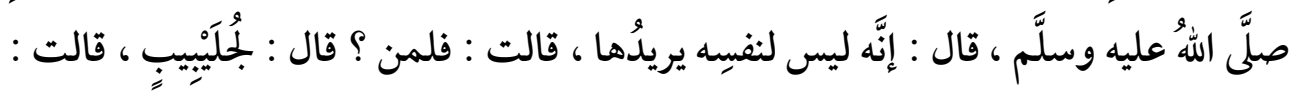

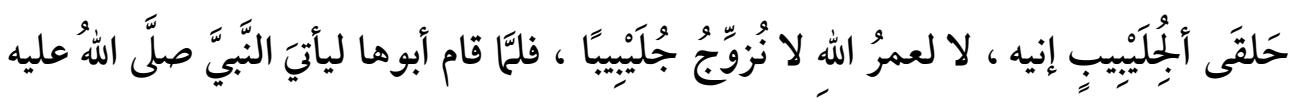

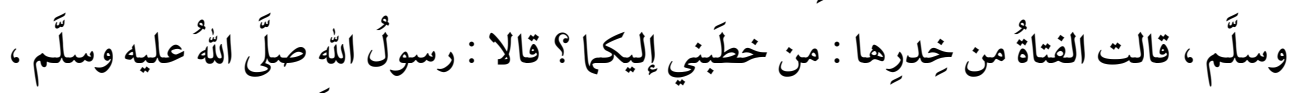

$$
\text { (1) - الدرر السَنية ، الموسوعة الحديثية ، شرح حديث رقم ع اهب }
$$




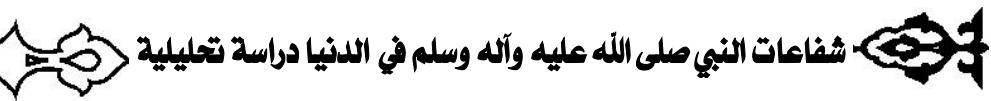

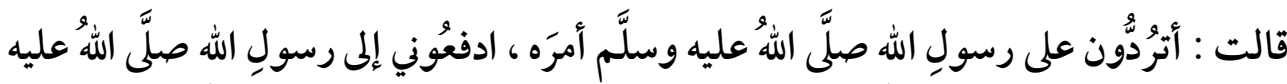

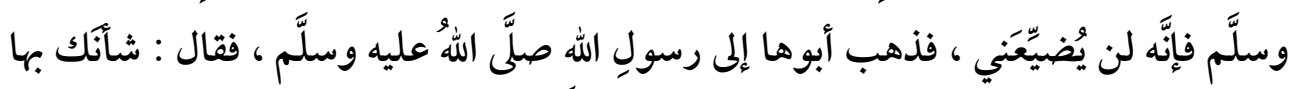

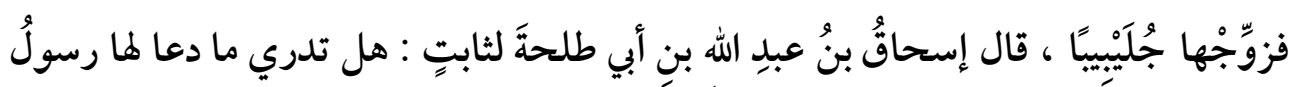

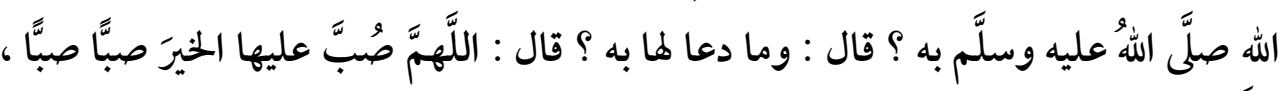

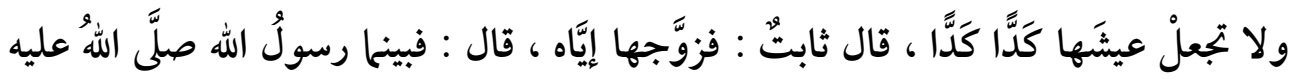

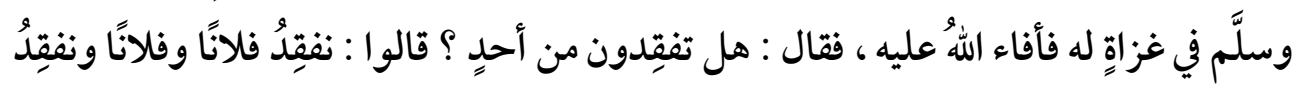

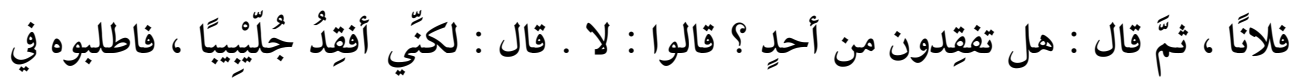

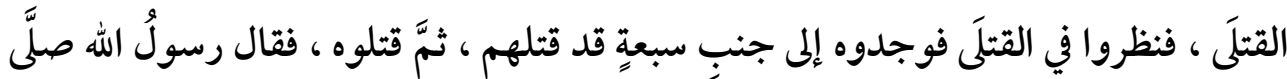

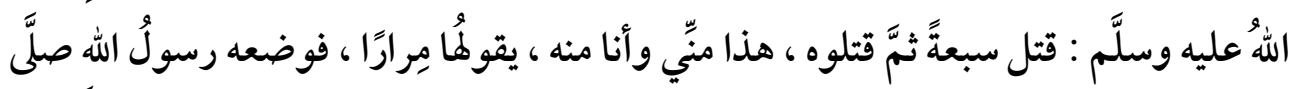

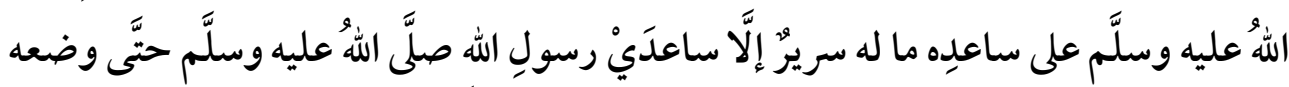

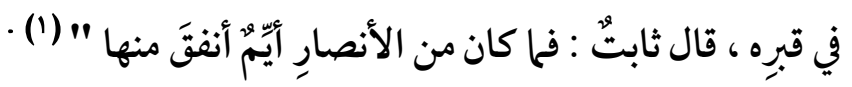

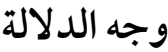

أن النبي صلى الله عليه وسلم طلب لجليبيب عروساً ، إلا أنهم رفضوا في البداية ، فلما علمت العروس أن النبي صلى الله عليه وسلم توسط له رضيت به ، كرامة وثقة منها برسول

(1) - رواه الإمام البيهتي، في شعب الإيان من حديث أبي برزة الأسلمي، وهو صحيح على شرط مسلم ،

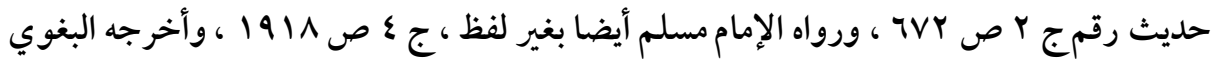

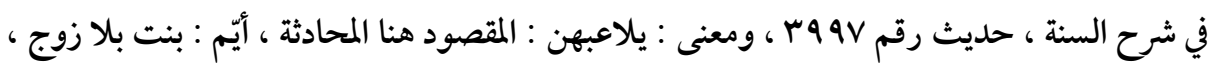

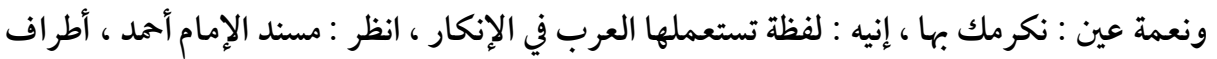

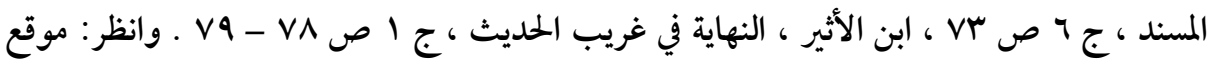

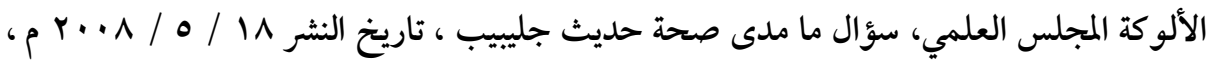
بواسطة شريف شلبي. 


\section{0}

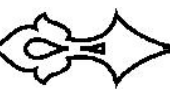

الله صلى الله عليه وسلم ، ثم إنهم لمّا أجابوه لما طلب دعا للعروس بالخير والبركة في الدنيا

$$
\text { والآخرة . }
$$

ولما كان صلَّل اللُّعليه وسلَّم في غزاة خرج معه جليبيب ، وبعد انتهاء القتال سأل أصحابه

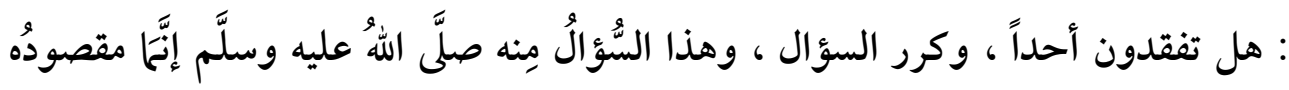

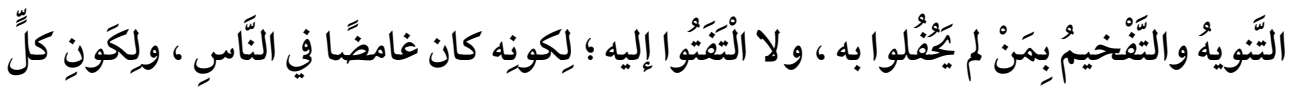

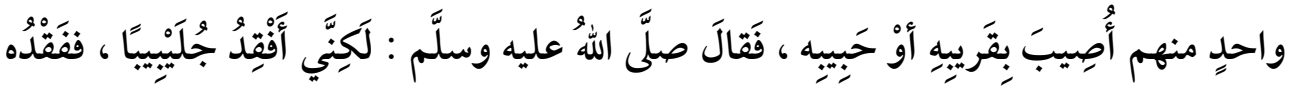

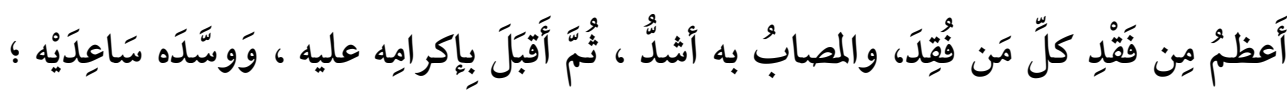

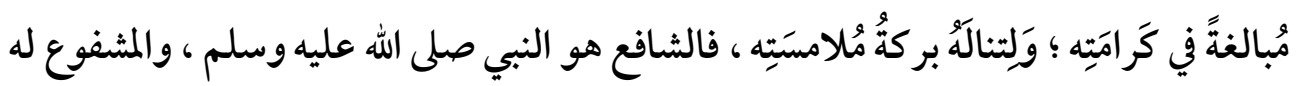

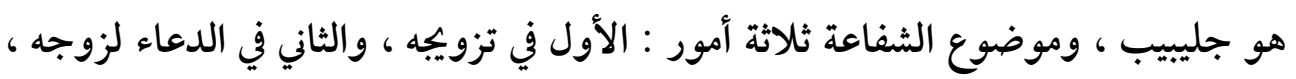

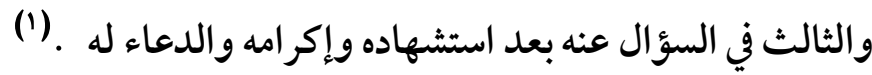

$$
1 \text { - شفاعته لأم هانئ : }
$$

روى الإمام البخاري بسنده عن أم هانئ بنت أبي طالب قالت : " ذهبتُ إلى رسول الله

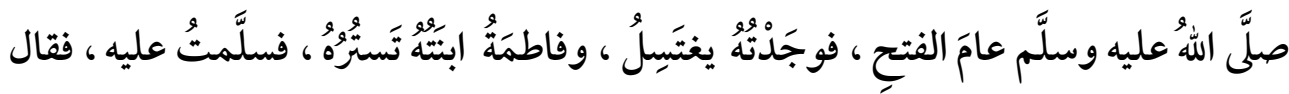

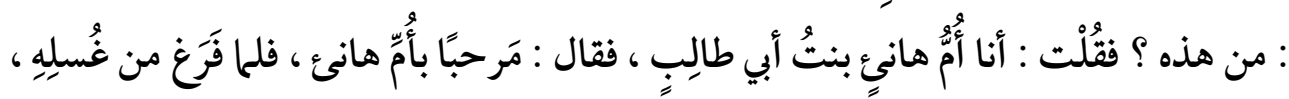

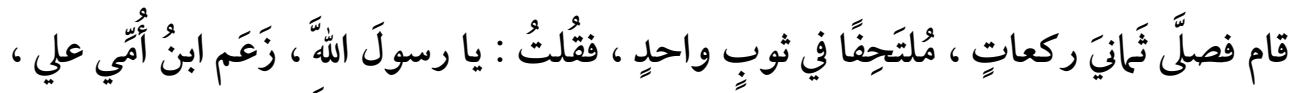

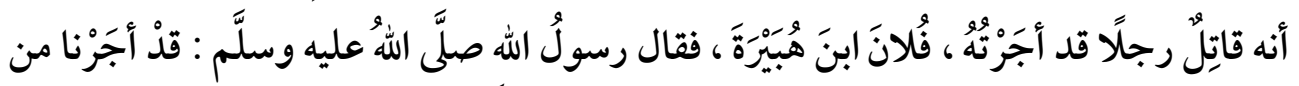

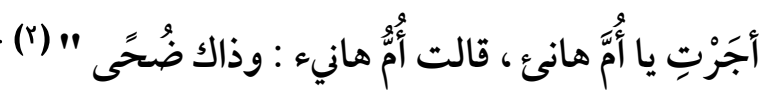

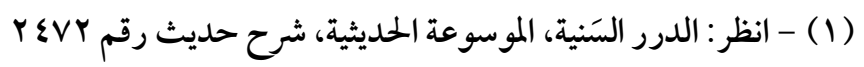

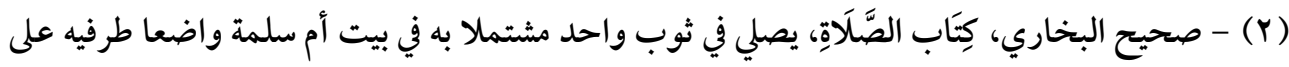

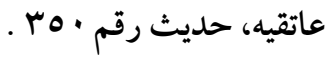

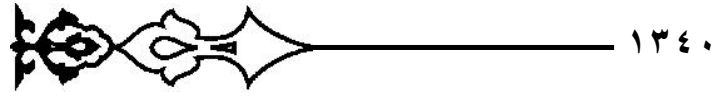




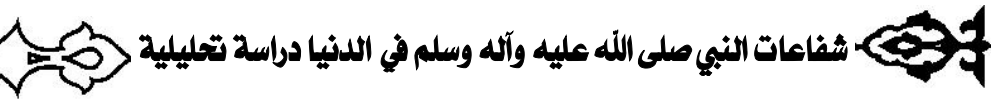

وجه الدلالة

أن النبي صلى الله عليه وسلم أعطى عهد الأمان لشخص كافر بناء على ما أَعْطَتْ أُمُّهُ هَانِيْ

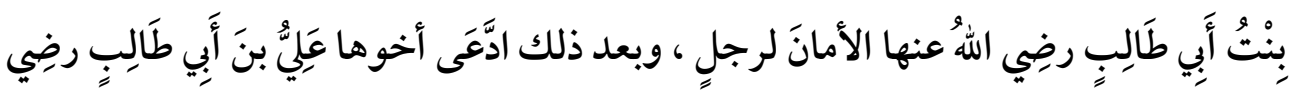

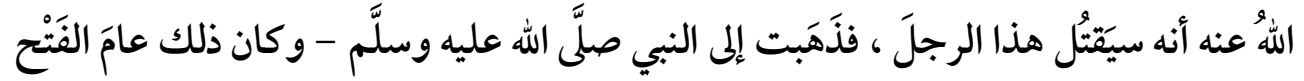

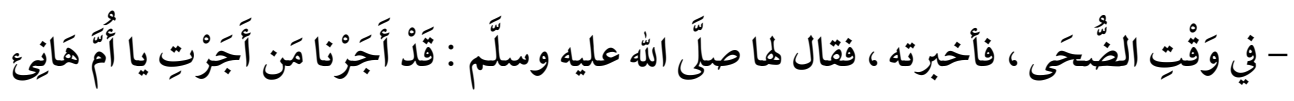

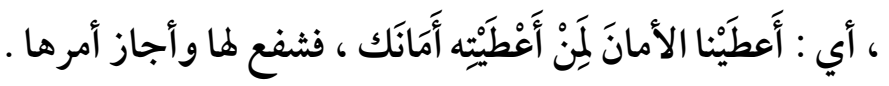

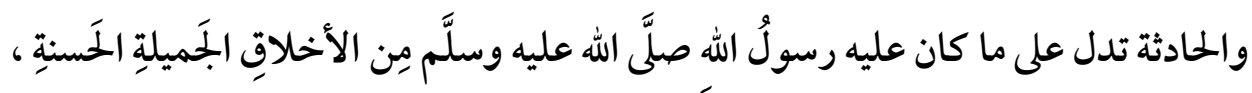

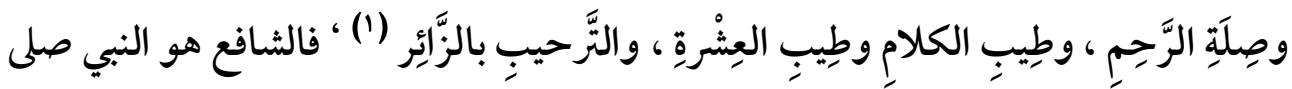

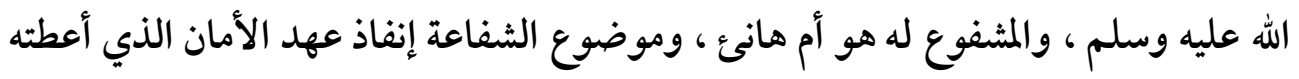

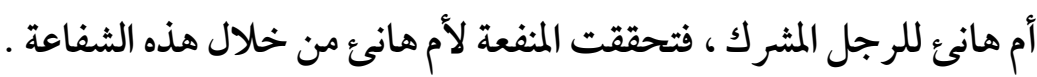


العدد الخامس والثلاثون

\section{الغاتـــــة}

وبعد هذا العرض لموضوع شفاعته صلى الله عليه وسلم في الدنيا للعالمين، يمكن تسجيل

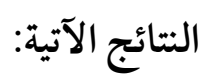

1 - أن الشفاعة ثابتة له صلى الله عليه وسلم في الدنيا كما هي في الآخرة، وأن شفاعته في الدنيا

$$
\text { شاهد ودليل على شفاعته في الآخرة. }
$$

r - أنه صلى الله عليه وسلم لم يشفع إلا لمن يستحقها، وكان له الإذن من الله في كل ما شفع

r - أن شفاعته قامت على أصل: وهو الرحة للعالمين، مصداقاً لقوله تعالى: "وما أرسلناك

$$
\text { إلا رحمة للعالمين ". }
$$

ع - أن شفاعته صلى الله عليه وسلم في الدنيا شملت المسلمين والكفار والحيوانات.

$$
\text { والحمد لله رب العالمين }
$$




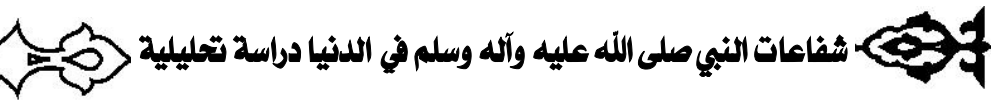

\section{تائمة المراجع حسب ورودها في البعث}

1 - الألوسي، أبو الفضل شهاب الدين السيد محمود ( ت · I I هـ ) ، روح المعاني في تفسير القرآن العظيم والسبع المثاني ، تحقيق محمد أحمد الأمد وعمر عبد السلام السلامي ، دار إحياء التراث العربي ، بيروت لبنان ، ط ال عام 1999 م ـ r - الدمشقي ، أبو عبد الله محمد بن أبي بكر ( المثهور بابن قيم الجوزية ) ( ت اOVVه) ، مفتاح دار السعادة ومنشور ولاية العلم والإرادة ، تحقيق الأستاذ سيد عمران والأستاذ علي

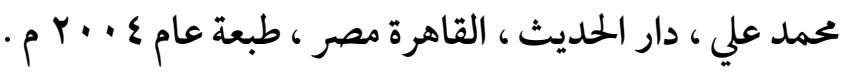
r - القرطبي، أبو عبد الله محمد بن أحمد الأنصاري (ت الIV هـ)، الجامع لأحكام القرآن الكريم، تحقيق سالم مصطفى البدري، دار الكتب العلمية، منشورات محمد علي بيضون، بيروت لبنان، ط ا عام .... ب م م. ع - ابن منظور، أبو الفضل جمال الدين محمد بن مكرم ( ت ل VII ) ) لسان العرب ، طبعة مراجعة ومصححة بمعرفة نخبة من السادة الأساتذة المتخصصين ، دار الحديث ، القاهرة

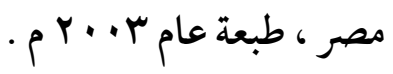
ه - الفيروز آبادي، أبو الطاهر مجد الدين محمد بن يعقوب (ت 1 1 هـ)، القاموس المحيط، اعتنى به وفصله حسان عبد المنان، بيت الأفكار الدولية، بيروت لبنان، طبعة عام ع · . F م. 1 - إبراهيم أنيس وعبد الحليم منتصر وعطية الصوالحي ومحمد خلف الله أحمد، المعجم الوسيط ، دون دار نشر ، ط ا عام I I I م م.

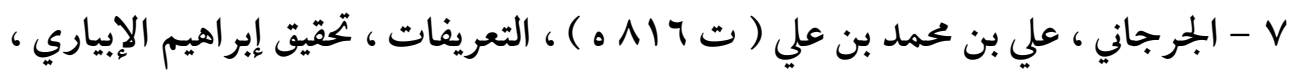

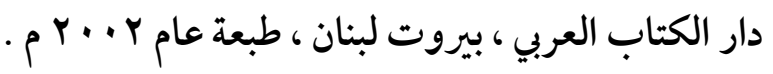

^ - ابن الأثير ، مجد الدين أبو السعادات المبارك بن محمد بن محمد الثيباني الجزري ( ت ج ·7 هـ ) ، النهاية في غريب الحديث والأثر ، تحقيق طاهر أحمد الزاوي ومحمود محمد 


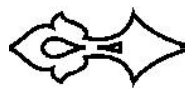

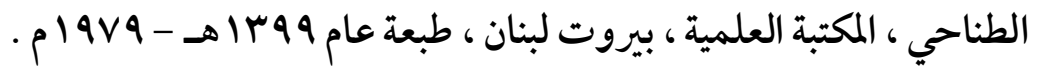
9 - التهانوي ، محمد بن علي(ت 1101 هـ )كثاف اصطلاحات الفنون،وضع حواشيه أحمد حسن

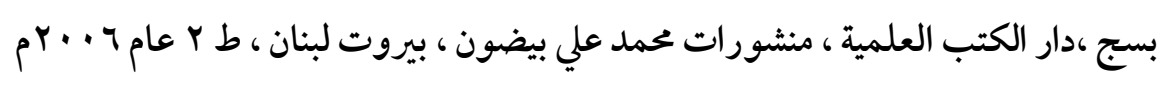
• 1 - محمد أحمد الحاج وبسام علي العموش ، قاموس العقيدة ، الأكاديميون للنشر والتوزيع

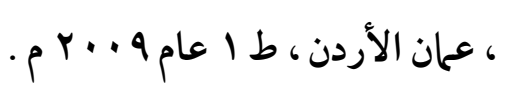
11 - الشنقيطي ، محمد الأمين بن محمد المختار الجكني ( ت سوها ه ه ) ، أضواء البيان في

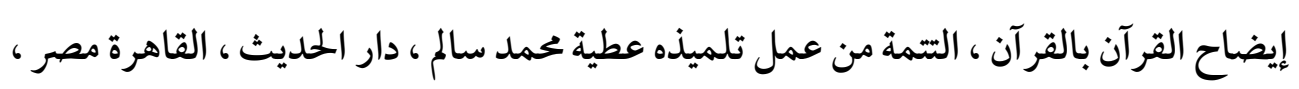
الناشر مكتبة العلوم والحكم بالمدينة المنورة ، طبعة عام ج + . Y م . r I - النيسابوري ، مسلم بن الحجاج ( ت الTY ه ) ، صحيح مسلم ، تحقيق نظر بن محمد

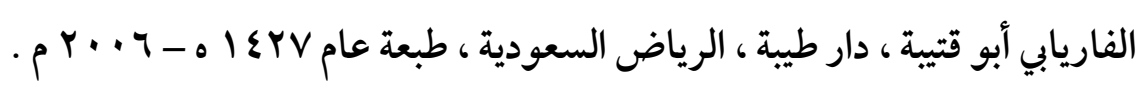

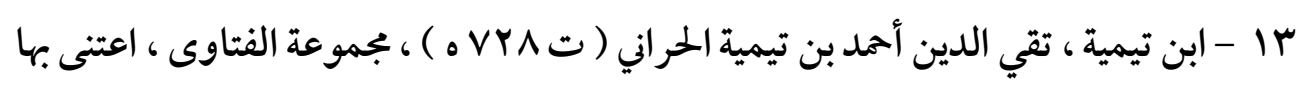

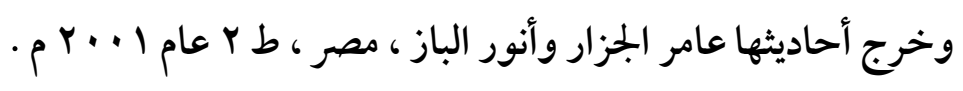
ع 1 - ابن خزيمة ، أبو بكر محمد بن إسحاق ( ت السبه ) ، التوحيد ، قدم له ووضع حواشيه وعلق عليه بجدي بن منصور بن سيد الشورى ، دار الكتب العلمية ، منشورات محمد

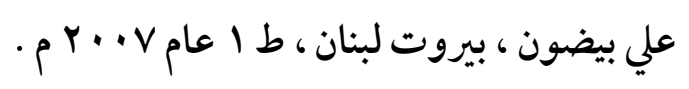

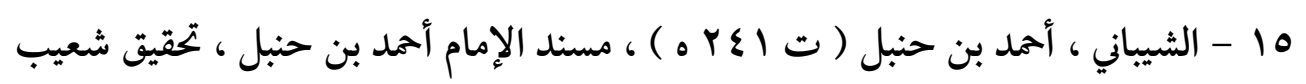

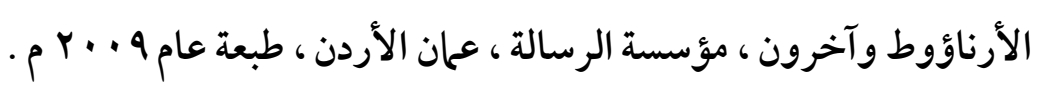
17 - البخاري ، محمد بن إسماعيل ( ت ب0 Y ه ) ، صحيح البخاري ، تحقيق محمد زهير بن

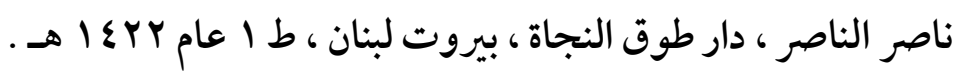
IV /https://www.dorar.net 


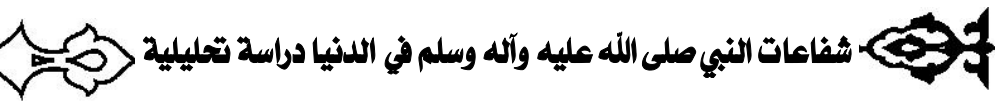

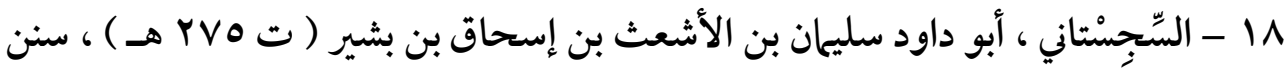
أبي داود ، تحقيق محمد محيي الدين عبد الحميد ، المكتبة العصرية ، بيروت لبنان ، طبعة عام

p $r \cdot 1 \cdot$

19 - ابن الملقن، سراج الدين أبو حفص عمر بن علي بن أحد (ت ع • 1 هـ)، البدر المنير في تخريج الأحاديث والأثار الواقعة في الشرح الكبير، تحقيق مصطفى أبو الغيط وعبد الله بن سليمان وياسر بن

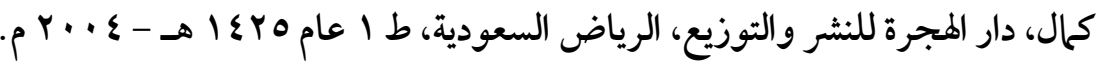

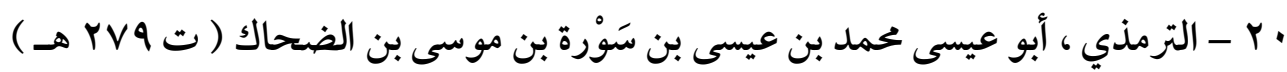
، الجامع الكبير - سنن الترمذي ، تحقيق بشار عواد معروف ، دار الغرب الإسلامي ، بيروت لبنان ، طبعة عام 1991 م م.

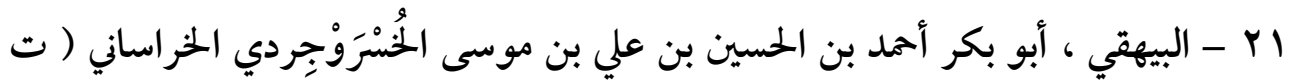
1 1 هـ ) ، شعب الإيهان ، حققه وراجع نصوصه وخرج أحاديثه الدكتور عبد العلي عبد الحميد حامد ، أشرف على تحقيقه وتخريج أحاديثه نختار أمد الندوي ، صاحب الدار السلفية ببومباي - المند ، مكتبة الرشد للنشر والتوزيع بالرياض بالتعاون مع الدار السلفية ببومباي

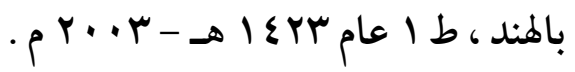

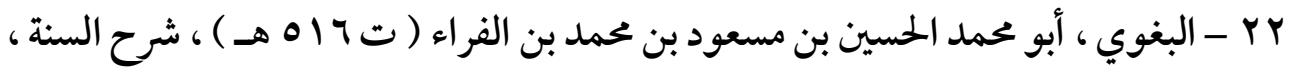
تحقيق شعيب الأرناؤوط ومحمد زهير الشاويش ، المكتب الإسلامي ، دمشق بيروت ، ط ب عام r. $1 \varepsilon$

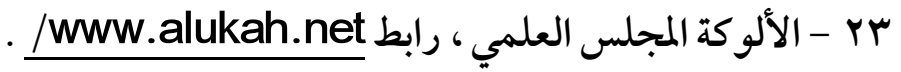


العدد الخامس والثلاثون .
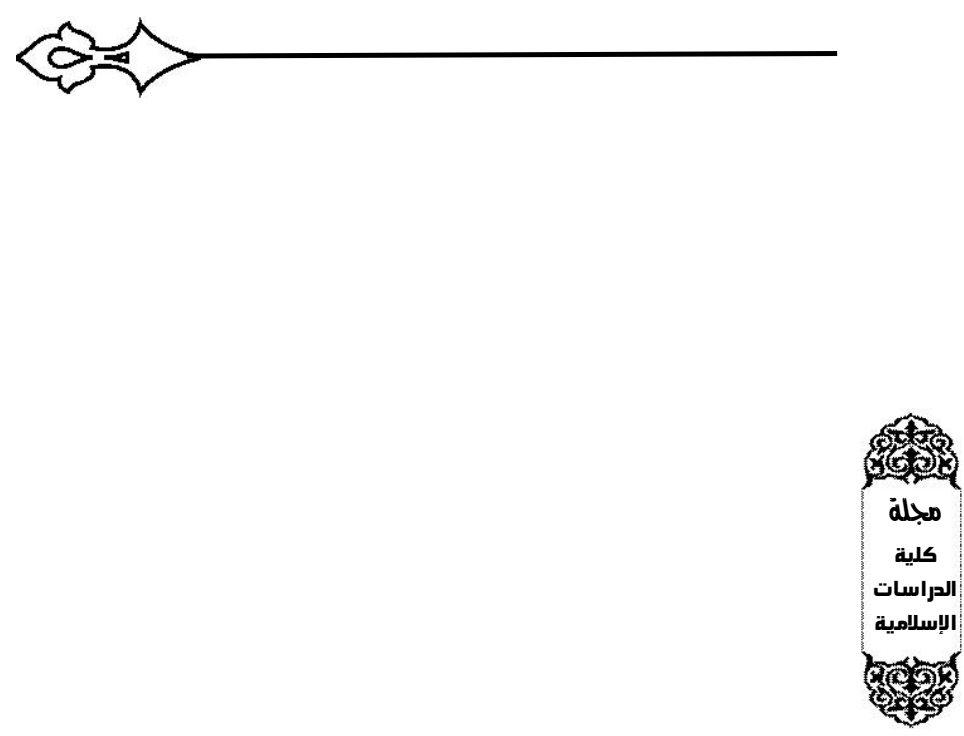

( 